\title{
$J(\Theta)$
}

Received: 31.01 .2019

Accepted: 01.02.2019

Published: 24.06 .2019

JOTS, 3/2, 2019: 321-371

\section{Additional Turkic and Tungusic Borrowings into Yukaghir III}

\section{Yukagir Dilindeki Türkçe ve Tunguzca Alıntılara İlaveler III}

\author{
Peter PIISPANEN \\ Stockholm University (Stockholm/Sweden) \\ E-mail: peter.piispanen@finska.su.se
}

Continuing on previous research, in this part of a paper series, a total of thirty-nine newly found suggested borrowings from the Turkic, Tungusic and Mongolic (and Russian) languages into the Yukaghir languages and dialects of far northeastern Siberia are presented as loanword etymologies, which is followed by the discussion of a few tentative cases. The chronology of the borrowings is considered, and solid phonological and semantic considerations are given for each suggestion, and other possible cognates or borrowings in the surrounding languages are also discussed. Further, some transcriptional corrections to the documentation of older Yukaghir lexicon is suggested. The results again highlight the extensive historical social contacts between the Yukaghir populations and surrounding tribes.

Key Words: Borrowing, Tungusic, Turkic, Mongol, Yukaghir. 


\section{J(৫)}

\section{Part I}

\section{Introduction}

The research herein continues the presentation of new suggested borrowings into the Yukaghir languages of the far northeastern Siberia from Turkic, Tungusic, Mongolic and Russian sources. For discussions and details regarding the chronology, phonology, prosody, estimated dating, etc. I will refer to the previous parts of this paper series, in particular the first part (Piispanen 2018). My own stance on the whole "Altaic" language hypothesis was presented in the second part of this paper series in some detail (Piispanen 2019).

During this line of research, I have had the great pleasure and privilege to receive further comments, suggestions and insights from several well-known Turkologists, Tungusologists and Mongolists, at the draft paper stage, which has vastly improved the details and presentation in several ways. I have gratefully been able to improve my documentation and methodology and to extend the data gathering and comparisons to include numerous vital glossaries, in most cases trustworthy ones, and to find all the key references for exactly this type of research. In short, regarding lexicography, I will mention the following key works used throughout all of this:

Yukaghir

1. Nikolaeva 2006 presenting Late Proto-Yukaghir reconstructed forms, and also collecting and gathering lexicon from numerous older and newer Yukaghir languages and dialects in a comprehensive manner; 2. Kurilov 1990, 2001 and Atlasova 2007 three indispensable dictionaries of the Tundra Yukaghir languages; 3. Nikolaeva-Shalugin 2002 a brief dictionary on the Kolyma Yukaghir language; 4. Spiridonov 1997 and 2003 two useful dictionaries on the Kolyma Yukaghir language.

Turkic

5. Sleptsov 1972 a most useful dictionary on the Yakut language; 6. Pekarsky 1959 an extremely extensive Yakut dictionary; 7. Vasiliev 1995 more on the Yakut language, 8. Clauson 1972 a useful compilation of old Turkic, the collections of 9. VEWT, 10. EDT, 11. ESTJA, 12. Leksika, 13. Fedotov I \& II detailing numerous Turkic languages. 


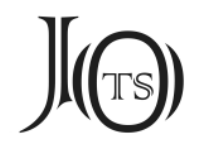

Tungusic

14. Cincius 1975 and 1977 an excellent comparative compilation of Tungusic lexical materials; 15. Robbek-Robbek 2005 a simplified but useful dictionary of the Ewen language; 16. Vasilevič 1958 an excellent dictionary of the Ewenki language).

Mongolic

17. Lessing 1960 the probably greatest dictionary of Written Mongolian up to date; 18 . Nugteren 2011 a thesis including numerous detailed Proto-Mongolic reconstructions, general Altaic 19. Starostin et al. 2003.

At times, I other research of importance, relevance or notice has also been consulted and referenced where relevant for the discussion. ${ }^{1}$

\section{Some corrections to Yukaghir documention}

Before proceeding with presenting the further suggested borrowings into Yukaghir, I will take the opportunity to correct some errors in the scientific literature. I have very often used NIKOLAEVA's A Historical Dictionary of Yukaghir (2006) in my research, and therein she has compiled Yukaghir lexicon from numerous different sources. Her method of transcription of Russian sources in the Romanized alphabet is clear. Thus, following Nikolaeva's own transcription system, and checking the original sources, I will below present corrections to a few erroneously given forms (it should be noted that there are actually more errors than these, as has also been pointed out by various reviewers of the dictionary). Errors in documentation of this type are important to catch early before they propagate further in future scientific literature. The errors discussed here relate to the records of the Chuvan and Omok materials of Matjuškin in Wrangel (1841, collected during the expedition of 1821-1824), and to the Kolyma Yukaghir forms recorded by Spiridonov (2003), respectively. In NIKOLAEVA's dictionary, these are generally referred to as MC, MO (Nikolaeva 2006: 25) and SD lexicon, respectively. Some doubt may justifiably be cast about the accuracy of the transcribed forms

1 I wish to thank my colleagues Mikhail Zhivlov, Eero TALVITIE, Marco CRNOBRNJA, Juho PYSTYNEN, Aurélius QUIDAM and Mikhail KOLODYAZHNY for their valuable and useful input on an earlier draft version of this paper. All remaining errors are, of course, my own. 


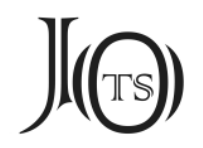

\section{of older Yukaghir lexicon, but the records must still be kept straight and to the point as documented:}

It should be MC puguč 'hot; heat' (Wrangel 1841: 119), not MC pugus 'sun' as reported in Nikolaeva 2006: 366 . While there are a few MC derivatives of this root, the word cited in the dictionary is indeed affricate-final, not sibilant-final.

It should be MC omoć- 'good' (Wrangel 1841: 119), not omoč- 'good' as reported in Nikolaeva 2006: 327 . The affricate in the source was actually followed by a soft sign (in contrast to a hard sign), which changes the phonological value of it accordingly. NiKoLAEVA does correctly note that the affricate is already palatalized (regardless of whether it is followed by a soft sign or not; Nikolaeva 2006: 7), but since Yukaghir actually differs between č and ć, I believe that this distinction - which I think Fjodor Matjuškin was trying to make - must also be taken into account with this word.

It should be MC jemobis 'black' (Wrangel 1841: 119), not MC emobis 'black' as reported in Nikolaeva 2006: 157. Indeed, NiKOLAEVA does note that a reported initial $e$ - in the source could denote either a je- or an $e^{-}$(2006: 7). However, this word was instead originally documented using the Russian je-sign, although the proto-form no doubt had only an $e$ - with this root as evident from the other Yukaghir cognates.

It should be MC ekčen' 'little' (Wrangel 1841: 119), not jekčeñ 'little' as reported in Nikolaeva 2006: 252. This error is similar to that found above and is likely just an oversight in the romanized transliteration for the dictionary.

It should be MO jules 'night' (Wrangel 1841:120), not MO juleś 'night' as reported in Nikolaeva 2006: 197. The original source documentation lacked any trace of palatalization, and so the word ends in a regular -s.

It should be SD oqna-angil 'window, lit. window opening' (Spiridonov 2003: 23), not SD oqnqangil 'window' as reported in Nikolaeva 2006: 323. This is an obvious typo as $q$ and a are next to each other on the keyboard. In this compound, the individual parts are not connected through any genitive marker (which in this case would have been *-nt-).

It should be SD jaglogal 'туловище = torso' (Spiridonov 2003: 15), not SD jaglagol 'body, torso' as reported in Nikolaeva 2006: 180). This is another typo where two vowels have just switched places. In NIKOLAEVA's entry the SD word was then compared to TD yahabon-molil 'lumbar vertebrae' (< molil 'groin'), which resulted in the reconstructed PY *jaya *jayqa. The comparison seems accurate, but the reconstruction uncertain, although only the first of the two reconstructed forms, *jaya, should apply if accurate.

As a final note in this chapter, another Yukaghir etymology can be presented for a MC word, namely: MC mandžea 'fire' (p. 15), belongs to PY *memč z- > 


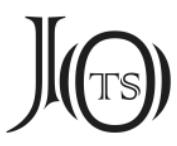

KY memžaja, mömžaja 'flame', etc. (Nikolaeva 2006: 263). Both the phonological and semantic correspondence are sound and obvious and require no further comments.

\section{Borrowed grammatical markers}

A noteworthy find is the fairly extensive degree of borrowing of grammatical markers into Yukaghir from Yakut and Ewen. Earlier, some borrowed markers from Russian are also known. Briefly, the following previously discussed, borrowed markers, or interjections - or secondarily developed markers from borrowed lexical roots - should be mentioned:

KY ajayz 'modal marker (optative)', ajmič 'modal marker (it is nice that)' < KY aja:- 'to rejoice, to become happy', etc. which is borrowed (Nikolaeva 2006: 97) from TU *aja- ${ }^{*} a j u-$ 'good; beautiful' (TMS 1:18-20).

KY d'a 'interjection: well, so', borrowed (Nikolaeva 2006:148) from Ewen d'e (TMS 1: 279).

KJ bič 'emphatic marker', borrowed (Nikolaeva 2006: 118) from Rus. biš ‘бишь = a grammatical particle'.

KD xabuč 'intensifying marker', borrowed (Nikolaeva 2006: 200) from dial. Rus. kabyś.

KY qata 'hortative marker'; KJ qata 'here it is'; KD xate, xata 'intensifying marker'; TK qate 'better, utterly', borrowed (Nikolaeva 2006: 381) from Ewen qata 'хорошо, что ... к счастью = it is fortunately good that...' (TMS 1: 383) or Yakut qata ' модальное слова выражает противоположность сказанному или ожидаемому: наоборот, напротив; выражает предпочтение: лучше; выражает радость говорящего, ожидавшего худшего; выражает решительное утверждение, уверенность; выражает стремление говорящего ободрить собеседника; выражает резкий или внезапный переход к другой мысли = modal word that expresses the opposite of what was said or expected: conversely, opposite; expresses a preference: better; expresses the joy of a speaker that was expecting the worst; expresses a strong statement, confidence; expresses the desire of the speaker to encourage the interlocutor; expresses a sudden or sudden transition to another thought' (JRS 488). Sorting out the borrowings here is tricky, but I suggest, considering the semantics of the Ewen and Yakut forms, that the forms in the KY, KD and TK dialects are derived from Yakut. The KJ form, however, appears closer to the meanings found with Ewenki qata 'вот возьму; еще, все еще; снова, опять; ведь, вероятно; все равно; тоже = here it is; yet, still; again; after all, probably; does not matter; also' (TMS 1: 383), with the Ewenki form also being borrowed from Yakut. 


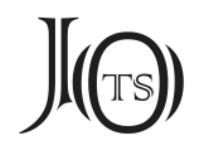

KY ošto: 'hortative marker' borrowed (Nikolaeva 2006: 417) from Rus. štoby 'чтобы = (in order) that'.

KY kuš-, kišs- 'although; free-choice pronominal marker'; KK kuš; KD kus-, kuč- ‘+ piece', borrowed (Nikolaeva 2006: 459) from Rus. хоt' 'хоть = though'.

The borrowing of such markers, functioning as clitics, suggests intense language contact situations, with multilingualism and code-switching in common speech. The borrowed markers here are either markers for certain grammatical functions as free morphemes or interjections. In addition to the four new suggestions presented below, there are quite certainly additional borrowed (=non-etymologized) markers to be found.

\footnotetext{
New borrowing

Yakut ere 'частица: выражает смягчение категоричности повеления, просьбы; частица: выражает угрозу или строгое предупреждение; попробуй, посмей; частица: выражает ограничение, выделение; частица: употребляясь с деет р.; только, лишь (только); как только = particle: expresses the softening of a categorical command or request; particle: expresses a threat or severe warning; try (it), dare; particle: expresses a constraint or limit; particle: being used with children; only, just; as soon as' (JRS: 546), borrowed as: КY еre 'только (что); only; as soon as; indefinite pronominal marker' (NikolaevaShalugin 2003: 92 ; Maslova 2003: 545; Nikolaeva 2006: 164).
}

This represents another very useful grammatical marker borrowed verbatim only into modern Kolyma Yukaghir from Yakut. Yakut ere has numerous meanings and uses, a selection of which are presented above, and also functions merely as only and as soon as. These, as well as the grammatical functions, have here all been borrowed into KY. In fact, I suggest that the Yakut descriptions, which likely also carried over into Yukaghir use, may provide an extended clarification of the grammatical usage and functions of this particle also in modern Kolyma Yukaghir, hitherto only given as "indefinite grammatical marker". The borrowing is fairly recent and no doubt the result of code-switching Kolyma Yukaghirs being fluent in at the very least Yukaghir and Yakut (and Russian).

New borrowing

Ewen esni aj in esni aj bis 'нехороший, Недоброкачественный = bad, inferior' (RobbekRobbek 2005: 349), borrowed as: KY esnaj ‘modal marker: uncertainty’ (Nikolaeva 2006: 165). 


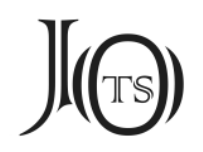

NIKOLAEVA notes that this unique KY marker is likely a recent borrowing, and indeed it is borrowed from Ewen. We can conclude the negating aspect of the Ewen term esni from this and other Ewen words and expressions: Ewen aj 'good, kind, glorious'; bisi 'located, available; condition'; nōd 'beautiful, attractive' give us: esni aj bis 'lit. not good condition = bad, inferior'; esni bis 'lit. not being available or located = not being something'; esni nōd bis 'lit. not beautiful condition = ugly'. Thus, in essence, esni negates a meaning. We can herewith note the lexical borrowing as Ewen esni aj (bis) 'bad, inferior' > KY esnaj 'modal marker: uncertainty'. The Yukaghir form is expectedly slightly phonologically altered, better fitting into the Yukaghir paradigmatic forms of markers. This borrowing is also fairly recent and, again, the result of code-switching Kolyma Yukaghirs being fluent, this time, in, at the very least, Yukaghir and Ewen.

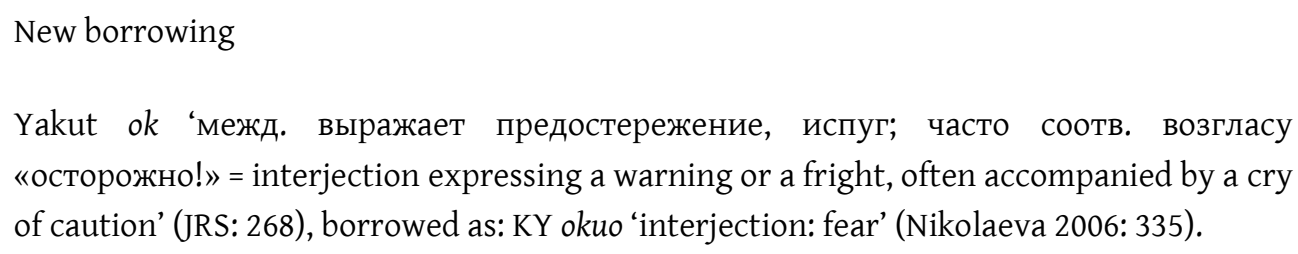

An interjection of fear has recently been borrowed into modern Kolyma Yukaghir. I surmise that this Yakut word also has a derivative in ok-sie 'межд. выражает удивление = interjection expressing surprise' (JRS: 268), but this version has not been borrowed into Yukaghir. NIKOLAEVA attempted to connect the KY interjection with TY oqodek, a modal marker of doubt, TK oqo 'suddenly', etc., but these must be considered unrelated words. I suspect that the word in Yakut may have originated in affective onomatopoeia (cmp. oh! akk! oy!). Natural borrowing of an interjection is again a strong sign of bilingualism, in this case of speakers speaking both Yukaghir and Yakut.

New borrowing

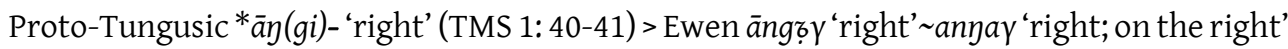
(Robbek-Robbek 2005: 44), borrowed as: TY ugune 'true', ugunemond'e 'honest' (Atlasova

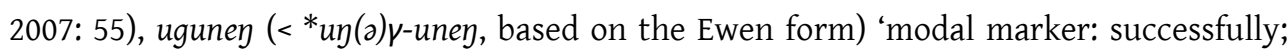
right, in the right time' (Atlasova 2007: 55; Kurilov 2001: 482), ejk-ugunen(-l'ie) 'by the way, lit. very successfully in the right time?'; TK ugunen; TD uguney ugune ugunon; TY ugunege(ne) 'by the way'; ugunegii- 'to believe smb.' (Nikolaeva 2006: 441). 


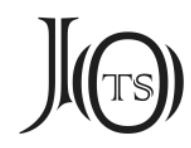

The here suggested borrowed Yukaghir forms are morphologically (and phonologically) very complex due to suffixation and subsequent phonological change, and therefore initially appear as a poor phonological match, but it can all be explained, hopefully convincingly. For the form uguney we can reconstruct

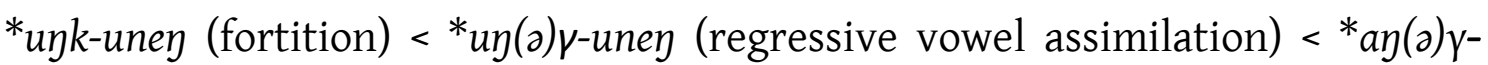
uney (through suffixation) (<Pre-Ewen *anyay-) The final -uney appears to create adverbs in Yukaghir, cf. TY qaquney 'however', numuney 'nothing'. Semantically the matter is fairly obvious with some secondary development in Yukaghir.

\section{New borrowings into Yukaghiric}

Below I present an additional eighteen new suggested Turkic, Tungusic and Mongolic borrowings into the Yukaghiric languages and varieties. This paper series continues to demonstrate that there are numerous more borrowings from various sources into Yukaghir than previously believed; it is therefore not at all justified, in a large number of cases, to reconstruct Late Proto-Yukaghir roots for such borrowings. Thus, the results of this paper series reduce the number of "known" Late Proto-Yukaghir roots, and instead provide loanword etymologies for a large number of previously believed native roots. Borrowings are most often to be found when a root is found within a geographically limited area, or solely in Kolyma Yukaghir, Tundra Yukaghir or another older dialect. Borrowings which are found to be very widespread in Yukaghir are logically to be considered very old. In a few cases, lexical borrowings are found to be so extensive that borrowing chains between a few languages have to be presented - in which case documentation and older research results have to correlate facts - unless these are, in the more extreme cases, instead widespread ancient Wanderwörte.

New borrowing

Proto-Turkic *ōt 'fire' (VEWT: 366; EDT: 34; ESTJA 1: 483-484; Leksika: 356, 361) > Turkish ot 'flame, fire (archaic use)'; Chuvash vot 'fire' (Fedotov: 1, 133); Yakut uot 'огонь, пламя; свет, освещение = fire, heat, flame; light, ray of sunshine or moonlight', Yakut uottā 'жечь, сжигать; поджигать; обеспечивать светом = to burn; to build a fire; to provide light', uottan 'приобретать огонь; сжигать что-л. (для себя, у себя); освещаться; = to be afire; to burn smth. (for yourself at home); to be illuminated' (JRS: 440; Pekarsky 1959: 3051-3053; Vasiliev 1995: 170), borrowed as: KY ottu: otul 'place where fire is made; camp; smb's hunting or fishing place' (Nikolaeva-Shalugin 2002: 56); SD uot (SD out (sic!) in Nikolaeva 2006: 


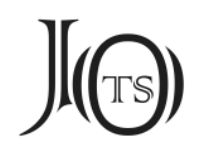

339); KY ottu:(ńa:)nuba 'place where fire is usually made' (Nikolaeva 2006: 339), ottuu 'fireplace' (Nikolaeva-Shalugin 2002:56), otu 'bonfire'; otuga ammalnuj 'campfire' (Spiridonov 1997).

A common Kolyma Yukaghir word for fireplace is a Yakut borrowing from the word for fire. Specifically, the SD form uot (from Spiridov's native Yukaghir works on Kolyma Yukaghir published in 2003) directly shows the non-suffixed, borrowed form (< Yakut uot). In Yukaghir, the root has obtained the nominal derivational suffixes - $u$ u (<PY ${ }^{*}-u$; Nikolaeva 2006: 83) or $-l$ (preceded by an epenthetic -u-) (<PY *-l; Nikolaeva 2006: 81), and also, on occasion, the word -nubo 'place', giving the literal meaning of fireplace. All of the attested Yukaghir words are seemingly fairly recent, and so this can be classified as a very recent borrowing. In particular, the long initial vowel of the SD form, lost in later Yukaghir languages, tell us that the borrowing was made directly from Yakut, also having a long initial vowel (actually a diphthong).

The same root is also present, although as a short-voweled form, in Ewenki atu 'bonfire', another Yakut borrowing (noted in Vasilevič 1958: 40). The Old Turkic form ot-čuq was also borrowed as Middle Mongolian očaq 'hearth' (Scherbak 1997: 196).

\footnotetext{
New borrowing

Proto-North Tungusic *čaK- 'to wrap up, to collect' (TMS 2:378) > Ewen čaq-; Ewenki čak'заворачивать, собирать = to wrap up; to collect', borrowed as: KD el-d'ahal'ne- (< el-čayal') 'negligent, untidy (of a housewife), lit. not collecting, not wrapping up'; TD el-d'ehalne(Nikolaeva 2006: 121).
}

The Tungusic root, while not very well-attested (it is only also found as Negidal čak-), is the likely origin of the Yukaghir words, which, however, a bit surprisingly are found in both Kolyma and Tundra Yukaghir. The Yukaghir forms can be segmented exactly as *el-čay-al'-no. The method of forming a new adjective by negating a foreign adjective, by using *el(')- 'not', is previously known in Yukaghir: cf. Rus. godnyj 'suitable', borrowed in KD as el'-godnono- 'unsuitable, useless, lit. not suitable' (Nikolaeva 2006: 168). Semantically, the meaning of untidy can well be equated with not collecting and not wrapping up, which describe the activities of not cleaning up a household. 


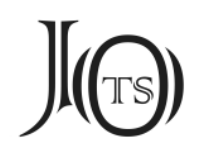

The Tungusic words are likely not Turkic borrowings (cf. Proto-Turkic *čak'to bind, fetters, harness', forms of which are found as Turkish čakil- 'to be bound, fastened (of yoke animals)', ča yan 'camel fetters', Middle Turkic čayan 'camel fetters', Gagauz čaqildaq 'rope harness', and Oyrat čaqi 'stick for binding horses'), since the root is not well-attested there either, the semantics are a bit different, and Yakut forms (i.e. of the prospective donor language into Yukaghir and/or Ewen/Ewenki) are missing altogether. Still there may be some sort of connection between these semantically and phonologically similar Turkic and Tungusic words. Given the lexical spread throughout these languages I believe that this root will also be found in additional Turkic and Tungusic languages, and perhaps also in some Mongolic languages. In any case, the most likely origin of the Yukaghir form, in this likely early borrowing, considering the geographic spread, is (pre-)Ewen.

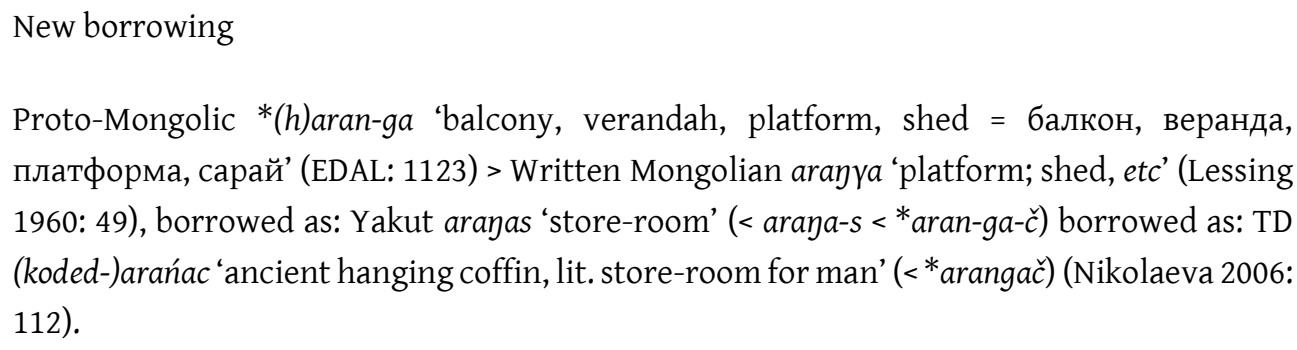

An old isolated word in Tundra Yukaghir with the documented meaning of 'ancient hanging coffin' can be shown to literally mean 'store-room of man', which can be a fitting description of a burial coffin. This can also be compared semantically to the Turkic cognate of Khalkha aranga 'platform, dais; shed; watch-tower' (Kałużyński 1995: 205). However, contrary to previous suggestions, the Yakut form is not derived from: Proto-Turkic *aran- 'shed; stable; fold; storeroom' (VEWT: 23, 66; EDT: 22; Leksika: 523-524). Rather, it is a Mongolic borrowing (as per: Anikin 2000: 93), as there are practically identical Written Mongolian aranga arapya 'вышка (для охоты на диких зверей) = tower (for hunting wild animals); oil derrick; platform; shed' (Lessing 1960: 49), as well as in far-away Kalmuck aryye 'balcony, veranda (in front of a house)' (Ramstedt 1935: 14), Khalkha aranga; Buryat aranga, and likely more (all hailing from a in the EDAL probably incorrectly reconstructed Proto-Mongolic form). Furthermore, the Yakut 


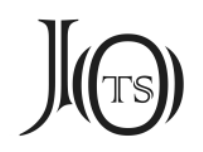

word has been borrowed also as Ewenki arayas 'навес (на высоких столбах); лабаз, кладовая (для хранения вещей) = canopy on high poles; storage shed' (TMS 1: 49) and dial. Rus. arangas 'навес на столбах у тунгусов для хранения запасов рыбы = canopy on poles near the Tungus for storing fish stocks' (Anakin 2000: 93).

For TD koded-arańac we can reconstruct *kode-nt-arangač as the borrowed form, where the compound consists of TD kode 'man' + -nt- (genitive marker) + the into TD borrowed arańas (<*arangač) 'store-room'. Two phonological changes require description: first, the word-final affricate $-c$ of the borrowed word likely came with the borrowing itself, suggesting that it was present in the Pre-Yakut word at the time of borrowing (despite NIKOLAEVA reconstructing *arajas for this word). In other words, the borrowing is fairly old. According to Marek Stachowski (2005: 202) the change ${ }^{*}-\check{c}>$ Yakut $-s$ appears to have been completed by the $16^{\text {th }}$ century, meaning that this borrowing into TD, where the affricate is retained, likely predates that time. Indeed, modern Yakut arayas is demonstrably from Pre-Yakut *aran-ga- $\check{c}$ (which carries a diminutive suffix), which contained such an affricate. Second, note also how the cluster ${ }^{*}-n g$ - became $-\eta$ - in modern Yakut, a change that, also according to Stachowski, was completed a bit later by the $17^{\text {th }}$ century; this engma, thus, cannot have been present when the word was borrowed into Yukaghir because the change producing the engma had not yet occurred in Yakut. In other words, here we can observe the change -ng- >-ń-in TD with this word (even though the change $-\eta->-n-$, which does not seem to apply here due to chronological considerations, is likely both more frequent and naturally occurring). Indeed, there are numerous examples where irregular changes between the two have occurred in Yukaghir lexicon, ${ }^{2}$ as well as between the engma and $n$, and between the engma and ng. Compare the following: KY jayž 'goose' - SD jangza 'id.' - TD yańd'e 'id.'; TY mongo 'hat' - TD mońo- 'id.' - MU mongó 'id.'; SD ngazi-paja 'whetstone' - KY náži:- 'to scratch, to comb; to wet, to sharpen'; SD engil 'abdomen of a fish' - KY eyul 'id.' \& KY jeniča- 'multi-colored' - TY jengur

ALBEIT I would like to argue that many of these changes are merely transcript artifacts, particularly in the older records where special signs, for example, for the engma were simply missing. In other case, however, and then in particular when comparing modern TY and KY, the change is a real observed and irregular one. 


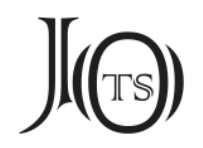

'id.', and more. With these matters clear, this can be considered another cultural borrowing from Yakut into Yukaghir.

\begin{abstract}
New borrowing
Proto-Turkic *obu-ra- 'to wear out (INTR), to decay; to cease, to stop' (EDAL: 308) > Yakut uuraj- 'переставать, прекращать(ся), кончать(ся) = to cease, to stop, to finish' (JRS: 448), borrowed as: TY aare(j)- 'остановиться; прекратить продвижение; прекратиться; остановиться (на ночлег); успокоиться = to stay; to stop (progress) (INTR); to stop; to stay for the night; to calm down (TR)', TK aarej-; TD arei-, etc. (Kurilov 1990: 15; 2001: 20; Nikolaeva 2006: 95; Angere 1957: 23).
\end{abstract}

The Tundra Yukaghir verb aarej- 'to stop' is decidedly borrowed directly from Yakut uuraj- 'to stop', with identical semantics. The phonological correspondences are fully explainable, and even the root-final suffix $-j$ of the Yakut verb is demonstrably retained at least in the older documented Yukaghir forms. While the vocalic correspondence is unusual it can be reasonably explained. The root-final change $-a->-e$ - in Yukaghir can be explained by a palatalization effect due to the following semivowel $-j$, as seen numerous times throughout Yukaghir lexicon. The root-initial long vowel, on the other hand, has irregularly changed from $\bar{u}$ - to $\bar{a}$-, but this has parallels found with other borrowings albeit with short vowels: Dial. Rus. upavan 'подол, подзор, кайма у кухлянки = hemline, valance, rim of a kuxljanka' (Anikin 2000: 585-586, which also suggests Koryak and Chukchi correspondences, which may be its ultimate origin), borrowed as: TY apawaan 'fringe of fur at the bottom of a coat' (Nikolaeva 2006: 444). Also: TU *muKa 'fur clothes' (EDAL: 920-921), borrowed as: PY *may- > KY mayil 'coat', etc. (Nikolaeva 2006: 256), and TU *muru(n) 'luck; mind' (TMS 1: 558), borrowed as: PY *ma:r- > TY maaruo- 'lucky; happy', etc. (Nikolaeva 2006: 258). ${ }^{3}$ This change, however, is by no means universal as the vocalism of numerous other borrowings containing $-u$ - is retained also into Yukaghir. Rather, the vocalic lowering effect found with

\footnotetext{
One day in the future, all earlier, unspecified Tungusic borrowing suggestions (where only the TU form is compared to the Yukaghir forms) need to be re-evaluated and the exact donor language be determined, which is actually fully possible considering that Ewen and Ewenki phonology, respectively, have some quite distinguishing marks and traces after having diverged from common North Tungusic. Expectedly, most TU borrowings will at least statistically then be found to be from (PreEwen, and the remaining ones from (Pre-)Ewenki.
} 


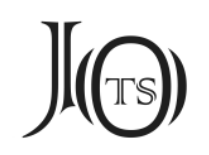

the aforementioned borrowings should only be considered an irregular feature, perhaps conditioned by hitherto undescribed (non-prosodically controlled) phonological conditioning factors; it could perhaps alternatively be attributed to dialectal variation (i.e. from unusual, or non-standard Yakut or Tungusic sources, although this would still not explain the Russian borrowing above). In any case, the Tundra Yukaghir words are clearly of Yakut origin, which in turns goes back all the way to Proto-Turkic.

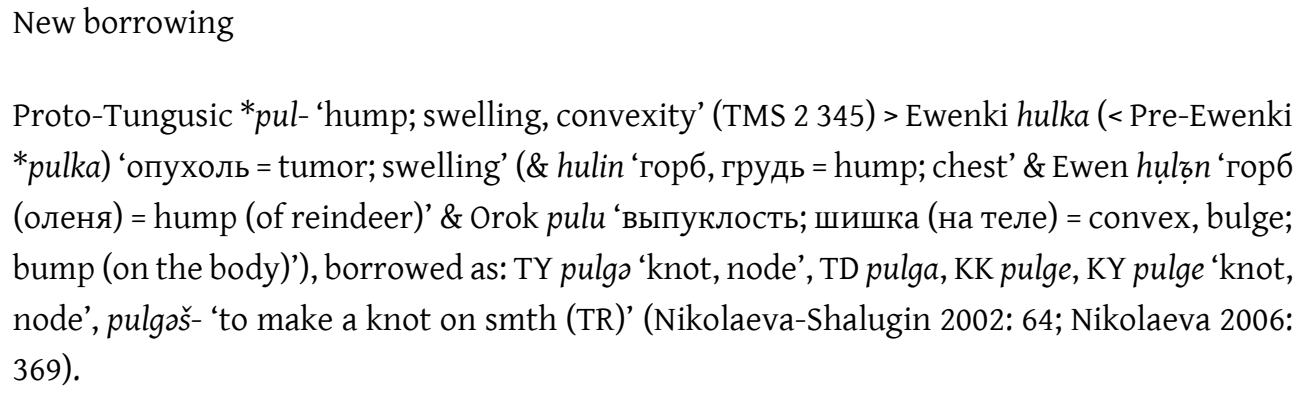

This presents another fairly old Tungusic borrowing into Yukaghir of excellent phonological and semantic overlap. The Yukaghir forms all suggest a borrowed form *pulko, which is a form fully adjusted to Yukaghir prosody. Considering that the root-initial plosive remains as $p$ - in Yukaghir, which was found also in Proto-Tungusic as ${ }^{*} p$ - for this root (reconstructable on the basis of the Orok form), but is now found as the voiceless glottal fricative $h$ - in the Ewenki form, the borrowing must be fairly old (i.e. from before the change of Proto-Tungusic $*_{p-}>$ Ewenki $\left.h-\right)$. A high age for this borrowing is also suggested by the geographic spread as it is found in both Kolyma and Tundra Yukaghir. As such, we can term the donor language Pre-Ewenki, with the reconstructed form of *pulka 'swelling', as it found itself into Yukaghir as the practically identical *pulka 'knot'.

Semantically, a hump is a large, raised area or part (on an object or a body). The original Tungusic meanings of 'swelling; hump; tumor' found themselves as the fully comparable 'knot, node' in Yukaghir, where a node (as a botanic term) is the part of a plant stem from which one or more leaves emerge, often forming a slight swelling, or (as an anatomic term) is a lymph node or other structure consisting of a small mass of differentiated tissue. 


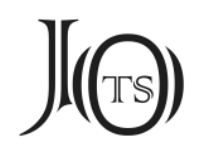

While all the above Tungusic words are clearly derived derivatives from Proto-Tungusic *pul- 'hump, swelling; convexity', one must further question if this is not actually identical to another root, namely Proto-Tungusic *bul- 'to spring up, to become convex, to pop out' (TMS 1: 106-109) both due to phonological and semantic reasons. These roots then (as noted in EDAL: 384 ) have direct Mongolic parallels with well-attested Proto-Mongolic *bul- 'swelling, lump' (with derivatives found in Written and Middle Mongolian, Khalkha, Buryat, Kalmuck and Dagur; this reconstructed proto-form is missing from Nugteren, $\mathrm{H}$. 2011). According to Anikin (Anikin 2000: 140) the Buryat form bula bulū bulxaj'to be convex', dial. Buryat bulduru(n) 'bump, knoll', is borrowed as dial. Rus. buldurun 'кочка = hummock overgrown with grass', which given the identical phonology and reasonable semantics seems a correct suggestion. Also, according to Doerfer (1985: 73) numerous Mongolic derivatives of this root (such as: Written Mongolian buldruu 'бугор, холм = knoll, hill'; Buryat boldiruu 'ухабы; прыщи, сыпь = bumps; acne, rash') are borrowed into the Turkic and Tungusic languages, although the borrowing directions and paths are not entirely clear. Besides, the Turkic root *bala-pan, also being used in the comparison, actually means large, thick, which is semantically not an accurate comparison. This is an expressive root which likely goes back to being borrowed very early between these languages, or actually be related elsehow. In any case, numerous derivational suffixes can be found throughout all the languages involved, and a few of them will display non-native elements (i.e. those forms can be identified as being borrowed from other languages), but the analyses require more research to clarify in full detail.

New borrowing

Proto-Tungusic *pulte- 'пробить = to pierce' (TMS 2:346-347) > Ewen hultzl- 'to break through'; Ewenki hulte- 'пробить, прорвать = to pierce, to break through', hultekē 'пробоина = (shell-)hole', borrowed as: KY puldagə- 'to be pierced, to become holed (of ice)(INTR); to mutter, to mumble (of a child), lit. to become holed repeatedly?', ?puldegetum 'to detach', ?puldenigie 'утка-нырок; гоголь = diver duck; eagle, lit. the piercer?' (Nikolaeva-Shalugin 2002: 64; Nikolaeva 2006: 370). 


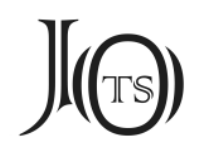

This is another fairly old Tungusic borrowing into Kolyma Yukaghir only, meaning 'to pierce through' (likely about ice during winter fishing), as shown by the phonology and semantics. The Tungusic root is attested in Ewen, Ewenki, Negidal xultejkin- 'прорваться = to break through', and in particular Orok paltikēi'идти по неокрепшему насту; проваливаться (о животном) = to walk on a flock; to fall through (of an animal)', Nanai poldo poldoram 'пробив насквозь = piercing through' and Manchu fondo 'сквозь; насквозь = through', etc. show that an original ${ }^{*} p$ - initial root can be reconstructed.

The donor language was either (less likely) Ewen or (more likely) Ewenki, and a common verbal root, Pre-Ewen/Pre-Ewenki *pulte- 'to break through', can seemingly be reconstructed based on the modern forms found in both languages. This root was borrowed directly into KY and further suffixed with -gว- $\left(<\mathrm{PY}{ }_{-}^{*}\right.$ $\gamma^{2}-$, an iterative verbal derivational suffix; Nikolaeva 2006: 80), thus obtaining a fully valid Yukaghir prosodic form for a three-syllabic verbal root, *pulte-ge- > KY puldaga-. While Ewenki hulte-ke is especially similar to KY pulda-ga- with regard to phonological structure, the suffixes must be considered independently added to the bare root as they consist of a nominal derivational root in Ewenki and a verbal root in Yukaghir, respectively. Further, KY has puldegetum 'to detach', and puldenigie 'diver duck; eagle' which appear to belong here on a phonological basis, although the semantics are unclear.

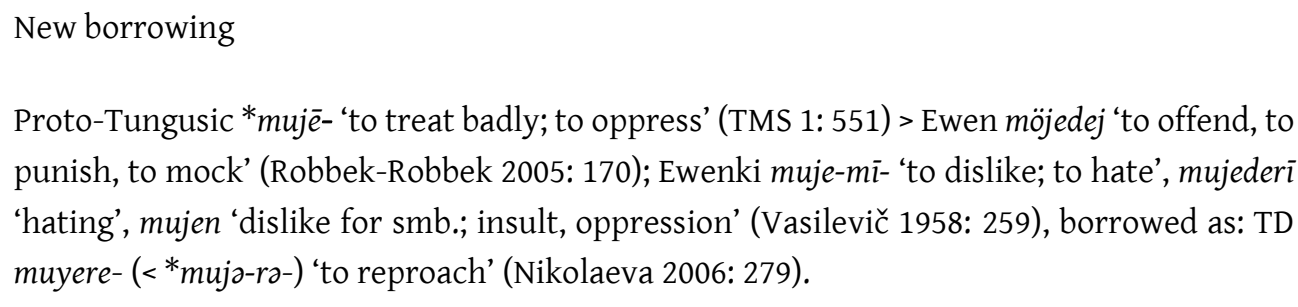
punish, to mock' (Robbek-Robbek 2005: 170); Ewenki muje-mi- 'to dislike; to hate', mujederi 'hating', mujen 'dislike for smb.; insult, oppression' (Vasilevič 1958: 259), borrowed as: TD muyere- (< *muja-ro-) 'to reproach' (Nikolaeva 2006: 279).

The rare, isolated TD verb muyere- (likely < *muje-ra-) is a clear Tungusic borrowing, seemingly from Ewenki as based both in phonological ( ${ }^{*}$ muje-, rather than *muja- because of the long, original $-\bar{e}-$ of the Ewenki form) and semantic considerations. Semantically, to reproach (Yukaghir) means to express to someone one's disapproval of or disappointment in their actions, which is synonymous to to 


\section{J(G)}

show someone dislike for some reason (Ewenki), or simply to treat someone badly. Additionally, in TD the final -re is a common transitive verbal suffix ( $<\mathrm{PY}{ }^{*}-r$; $\mathrm{Ni}^{-}$ kolaeva 2006: 82).

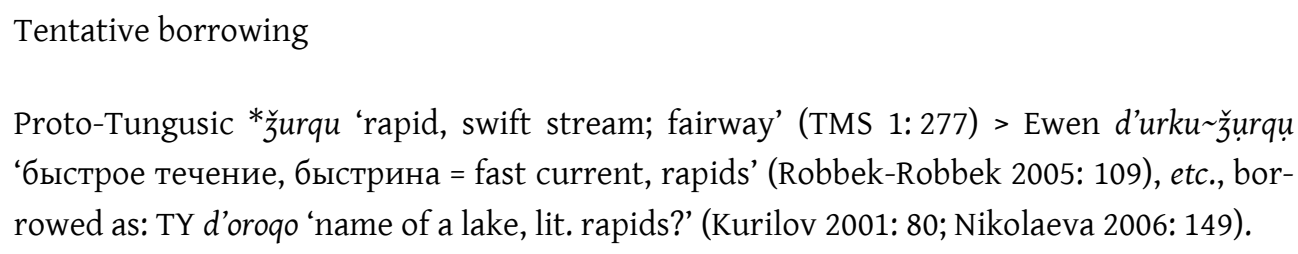

KURILOV documented d'oroqo - the name of a lake - in Tundra Yukaghir (exactly in this context: d'oroqo quodey el kuril'iitem - jalyin kirijek, which I would loosely translate as: Как не буду знать Дьорохо - название озера = as I will not know which d'oroqo - name of a lake), which NiKOLAEVA, despite also suggesting that the word is likely a recent borrowing (clearly based on the voiced plosives), then attempted to reconstruct on a Late Proto-Yukaghir level. The meaning of the name is indeed unknown - and I believe that a PY reconstruction is unnecessary - as a phonologically very close similarity with an Ewen word meaning rapids can be noted. Borrowing this word would only have required vocalic epenthesis to break up a consonant cluster and minor vocalic adjustment in Yukaghir (where ${ }^{*} u>0$ is very commonly observed).

Without being able to study the shape, surroundings or features of this particular lake, it can be noted toponymically that there are numerous lake rapids around the world, including Rapid Lake (Lac-Rapide in French) in Quebec, another around Thunder Bay in Ontario, another in the Nipissing District of Ontario and yet another in Kenora, Ontario, all four in Canada. Additionally, there are Rapid Lakes to be found in the Aleutians West area of Alaska, in Valley County in Idaho and in Sublette County in Wyoming, all three in the USA. In Finland, there is a Koskenjärvi (lit. rapids' lake), and another Koskenjärvi (Pahta Koskenjärvi) is found in the Gällivare Municipality of Norrbotten, Sweden, etc. As such, etymologically, there is ample precedent in naming a lake in order to describe the presence of particularly strong and distinctive currents within the lake area, for example if it were connected to a large brook or water fall. Thus, I suggest tentatively that the name of this (supposedly Yukaghir) lake is recently borrowed from the Ewen 


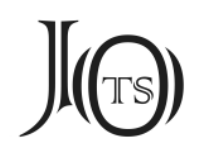

word for rapids; the Yukaghir documentation given above also suggests that there may be several rapid lakes in the area spoken about, with the speaker being uncertain about which one is being discussed.

The word is also found in Negidal žojku 'fairway', and so the direction of borrowing is into Yukaghir. This Tungusic root may also have some type of correspondence in Proto-Mongolic *dargil 'rapid currents' (mentioned in the EDAL: 404, although this reconstructed root is missing in Nugteren 2011), where it is attested in Written Mongolian dargil 'rapids in a river, rapid currents, torrent; swift stream; shoal in a river' (Lessing 1960: 233); Khalkha dargil and Kalmuck därg! (KW: 89). According to DOERFER (1985: 123), the Mongolic form is then borrowed as Ewenki dargi, etc., a precise and likely correct suggestion.

New borrowing

Proto-Tungusic *kilu- 'grey goose; heron; gull; swan, actually: a kind of seabird' (TMS 1: $392-$ 393, 429) > Ewen kular 'белая чайка = white seagull' (Robbek-Robbek 2005: 153), etc., borrowed as: TY kuul'aarma 'name of a lake, lit. gull lake?' (Kurilov 1990: 104; 2001: 174; Nikolaeva 2006: 226).

I believe the Yukaghir lake kuul'aarma borrows its name from the Ewen word for white seagull. In TY, the word-final cluster -rma is not to be considered native and must be an irregular composite. Therefore, the name of the lake likely reflects the common nominal derivational suffix -ma (<PY *-mə; Nikolaeva 2006: 81), which renders the literal meaning of kuul'aar-ma ( $<$ kular-mə) 'white seagull lake'. While A final, original schwa regularly turns into - $e$ in TY, it has here continued on to become $-a$, most likely due to progressive vowel assimilation (i.e. *arma > *-arme > -arma). All other vowels have been secondarily lengthened with the borrowing, which may reflect stressed positions. The lateral appears to have been spontaneously palatalized, a process not uncommon in Yukaghir.

Like in the previous toponymical suggestion, it is difficult to verify if this loanword etymology is actually correct or not, because we do not know if the lake in question is particularly rich in gull birds, if the name was originally given by Ewen speakers, or what Ewen populations themselves call this lake. However, there are numerous gull lake in the world, and thus ample naming precedent. 


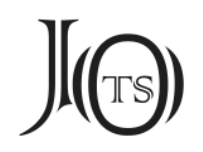

Still, the semantic and phonological overlap is good enough to consider this at least a tentative borrowing.

The EDAL compares the Tungusic root *kilu- to poorly attested Proto-Mongolic * kojil- 'wild turkey' (EDAL: 704), cognates of which are found only in Written Mongolian qojiluy and Kh. xojlog, but I suggest that this comparison is unjustified with circumstantial and superficial similarities only. As to the Tungusic root itself, it is difficult to conceive one Proto-Tungusic root describing as diverse birds as grey goose, heron, gull and swan (in: Ewen, Ewenki, Manchu, Ulcha, Nanai and Udege), other that if that root actually originally meant 'a kind of sea-bird'. Indeed, I believe that this hypothesis can be verified by the fact that the Tungusic root is an actual Eskimo borrowing: Proto-Eskimo *quli-(quli-) 'a species of small bird; plover' > Proto-Yup'ik *quli- *kuli- 'a kind of sea bird' (CED: 316), borrowed as: Proto-Tungusic *kilu- 'a kind of sea bird' > Ewen kil'arqa 'name of a bird (likely a gull species)', further borrowed as: KY qalerqa 'Ross' gull (Larus rosea)' (Piispanen, P.S. forthcoming).

Tentative borrowing

Proto-Tungusic *sēru 'rainbow' > Ewenki sērū- 'to cast all the colors of the rainbow; to flash (of lightning)', sērun 'радуга; молния = rainbow; lightning' (Vasilevič 1958: 348), sērūn'осветить (радусой) = irradiate', borrowed as: KJ šorune- 'white' (Nikolaeva 2006: 415).

This appears to be a rare Ewenki borrowing only documented in one dialect of Kolyma Yukaghir. A Tungusic root for rainbow has come to mean both rainbow and lightning (and irradiate) in Ewenki, and the latter meaning seems to have been borrowed into Yukaghir as the color of lightning (Ewenki) is practically white (Yukaghir). The EDAL (1264) reconstructs the Tungusic root as *siarū- 'lightning, rainbow; light' likely based not only on the Ewenki form, but also on Manchu šari 'light' and Orok sềrro, sịro 'lightning, rainbow', the other two cognates belonging to this root (TMS 2: 72), as well as, no doubt, on the possible well-attested Mongolic and Turkic correspondences, cf. Proto-Mongolic *sira 'yellow' (Nugteren 2011: 492) \& Proto-Turkic *siarig 'yellow (Common Turkic); white (Chuvash)' (with an agreeable Mongolic borrowing as Manchu sira (Rozycki 1994: 184) and another agreeable Bulgar Turkic borrowing as Hungarian sar sarga, dial. sarog 


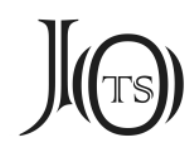

'yellow' (Gombocz 1912; Loránd 1967-1976/III: 227)). It is noteworthy that the meaning of white, just as in the Yukaghir form, is also found in Chuvash, which is forcefully claimed by the EDAL to be the original Turkic meaning. And additionally, aren't all the colors of the rainbow together white, and isn't light often interpreted as being white? Furthermore, the EDAL also compares the Tungusic root to a suggested Proto-Japanese sìruà- 'white' (JLTT: 840), and Proto-Korean *hắi'white' (Nam Kwang 1960: 482; Martin et al. 1967: 1898).

However, based only on the Tungusic words, I would instead opt to reconstruct this root merely as *sēru 'rainbow' as the final $-n$ I some Ewenki forms likely belong to a suffix, not being used in the Manchu and Orok forms. The first vowel was likely long as demonstrated both by the Ewenki and Orok forms, while the second vowel may have been short (but secondarily lengthened in some Ewenki verbal forms).

The Yukaghir form phonologically quite well matches the Ewenki forms although all vowels are short (likely simplified by prosody); additionally, the first vowel is -o- in Yukaghir instead of $-e$ - as in Ewenki but such switches between these two are known to exist irregularly in Kolyma Yukaghir exactly in this phonological context, cf. KY šöže-, šere(žə)- 'to embroider' (\& TY čaril'es- 'to make deep notches (TR), all being forms borrowed from TU *sere:- 'to embroider' (EDAL: 1234; Nikolaeva 2006: 414). These correspondences actually suggest that the vowel changes in this context are semi-regular rather than irregular, i.e. KY -ö/-e- TY - $a-$. However, it is not at all clear what triggers these changes, since there is also KY soromo 'man'; TD -soromo 'man', and records in numerous other dialects all with a retained first vowel. It would therefore seem that the cluster

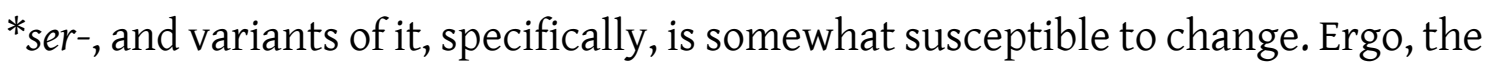
$\mathrm{KJ}$ form presented here with an -o- as a borrowing could well have developed from an earlier Tungusic - $e$ - (while a TY representative could have an - $a$ - in that place if found). The final $-n$ of the Ewenki form appears to have been reinterpreted as belonging to the Yukaghir suffix -nz-, while the change $*_{s-}>\check{s}^{-}$is fully regular in Kolyma Yukaghir. The borrowing, if correct, is likely fairly recent. 


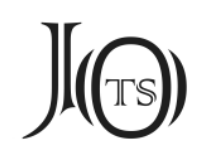

New borrowing

Proto-Turkic *kuba *koba 'pale yellow, pale grey' > Karachanid quba; Tatar quwa qiw, etc., borrowed as: Written Mongolian quba(n) quwa 'pale yellow; amber; rust' (Lessing 1960: 976; Scherbak 1997: 142), ${ }^{4}$ borrowed as: KY kube kuba 'ржавчина = rust'; KK kube; KY \& KD kubeńe- 'ржавый = rusty' (Nikolaeva-Shalugin 2002: 33; Nikolaeva 2006: 230). Likely also Mongolic borrowings into Yakut (serving as proxy language for the borrowing into Yukaghir) and Ewenki (see below).

The Turkic root is not attested in Yakut, and the reason for this may be found below. Interestingly, the from Turkic borrowed Written Mongolian quba quwa means not only 'pale yellow', but also 'rust' (although this meaning is missing in Lessing's dictionary), and 'amber', and both the phonology and semantics of this form agrees well with that found in Yukaghir; hence we appear to be dealing with another Mongolic borrowing into Yukaghir (likely through Yakut as proxy language). However, the history of this root may be quite complicated, and detailed suggestions follow below. There appears to be direct, to the Turkic form, equivalents in Mongolic and Tungusic with well-attested and suffixed (?) Proto-Mongolic *kubakaj 'pale, withered' (EDAL: 695; not included in Nugteren 2011) -which is borrowed as Oyrat qubarai 'pale'- and which is equally well-attested in Proto-Tungusic *kiaba- 'pale' (TMS 1: 386). ${ }^{5}$ Actually, apparently overlooked in previous research, I note that the Mongol form is also borrowed as Yakut kubaraj 'pale' (JRS: 184), which, based on both excellent phonological and semantic overlap, can herewith be etymologized as such.

There may be a few more borrowings going around from these roots. If we have a $b \sim g$ alternation in Yakut - which seems possible given all matters at hand - then we also have the otherwise, to the best of my knowledge, non-etymologized Yakut kugas 'рыжий, красный = ginger, red' (? <*kuba-č, a suffixed form),

4 According to other sources (Lessing, see above, and Rozycki 1994: 111) the Written Mongolian form could be borrowed from Chinese hup'o, but I believe this is phonologically indefensible and the likely donor for Mongolian is most likely Turkic. There is also Manchu quwa, which likely is a subsequent Mongol borrowing.

5 Although I must suggest that reconstructing it in this form may be in error; the various words in different Tungusic languages would instead suggest simply *kēm- or *kiam- followed by numerous different suffixes in different languages. 


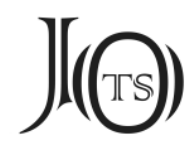

borrowed as Ewenki kugas kuvas "красная белка = red squirrel (Sciurus vulgaris)' (according to Vasilevič 1959: 216). Other known examples of $b \sim g$ alternation in Yakut include: Yakut sabadaaj Dolgan hogudaaj honudaaj 'a freshly caught fish in warm season, which is used in its raw state as an ingredient in a dish'. Yakut suba, dial. suga Dolgan huga 'cell layer located between the skin and meat, inside of the animal skin'. Yakut tugul tubul tumul Dolgan tugul 'bones (in the reindeer hoof)'. Yakut tugut tubut Dolgan tugut tubut 'reindeer calf'. Yakut ug(u)raa- uburaa- Dolgan uguraa- uburaa- 'to kiss'. All of these include back vowels, which supports the thesis that Yakut kugas indeed could originate in *kuba-č (as also borrowed from Mongolic and suffixed).

Throughout all of this, it should be noted that there is also a native word for rust in Mongolic, namely Proto-Mongolic *jebe 'rust' (Nugteren, H. 2011:385), but this remains wholly unconnected to the borrowing hypothesis at hand. The Yakut word itself would then seem not to be of direct Turkic origin (where the meaning is pale yellow, pale grey), but instead originate from the Turkic form borrowed into Written Mongolian as a proxy (with the meaning pale yellow, amber, rust). Then, as mentioned above, there is a separate borrowing from Mongolic into Yakut with the meaning of pale, so all in all Yakut borrowed two similar forms from Mongolic. The subsequent borrowing into Ewenki would be another one detailing an animal by its color. Indeed, the color of the red squirrel is polymorphic and varies from between black to red and between a thinner summer and a thicker winter coat with larger ear-tufts; during the summer this squirrel can indeed be orange, reddish or brownish (or rust-colored), as evident from any photograph taken of the species. So, in summary, and all in all, we appear to have a borrowing chain going through Turkic [pale yellow, pale grey] > Mongolic [pale yellow, amber, rust] > Yakut [pale \& ginger, red, respectively] (\& Yukaghir [rust]) $>$ Ewenki [red squirrel].

New borrowing

Proto-Tungusic * kusü̈- 'to fight; fight; strength; power' > Ewen kusin 'fight, battle, war', kusivdej 'to be beaten (of a fight, a god, a battle)', kusidēk kusikečék 'fight, battle; place of fights or battles, battlefield' (Robbek-Robbek 2005: 156); Ewenki kusi-mī 'to fight, scold, argue, contradict', kusin 'battle, fight, dispute, quarrel, war', kusikēttej kusidēj 'to fight, to beat' (Vasilevič 1958: 224), borrowed as: TJ kusheyej- 'to overtake' (Nikolaeva 2006: 229). 


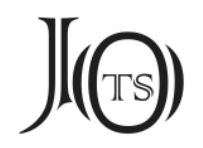

Both the phonology and semantics suggest that we are here dealing with an isolated Tungusic borrowing into the Tundra Yukaghir dialect denoted as TJ. However, it is not at all clear why the Tundra Yukaghir form would have changed into $\check{s}(=-s h$-) in this context; Tundra Yukaghir regularly displays $s$ where Kolyma Yukaghir displays $\check{s}$, both likely originating in an earlier *s and/or *'s, so we would have expected a regular -s- here. The semantics of the borrowing is fully comparable to that of another similar one: Yakut kuot- 'to run away, to overtake' (JRS: 190), borrowed as: TK kuote- 'to win a competition' (Nikolaeva 2006: 229); 'to overtake' - 'to win' of the older suggestion directly parallels 'to overtake' - 'to beat' with this new suggestion.

\footnotetext{
New borrowing

Proto-Tungusic *āj- 'swift; to run quickly; to step (on sand, snow)' (TMS 1: 21) > Ewen ajin ain 'fast, frisky, fast-footed, nimble, light of walking' (Robbek-Robbek 2005: 37), bor-

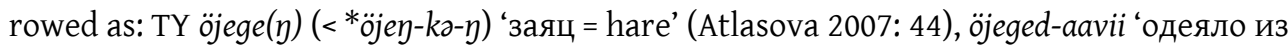
заячьей шкуры = blanket of hare-skin', öjegen-purie ‘a kind of berry, lit. hare's berry’; öjegerawa (< *öjen-kд-sawa) 'заячья шкура = hare skin', ojjegedie 'a man's name; the Little Dipper', öjege-laqil 'a star's name, lit. hare's tail'; öjegee 'a woman's name' (Kurilov 1990: 210; 2001: 353); TK öjege 'hare'; TD oyage-, etc. (Nikolaeva 2006: 322).
}

One Tundra Yukaghir word for hare is derived from a Tungusic word meaning to be fast(-footed). The Yukaghir word also has numerous derivatives (listed in Kurilov 2001: 353): TY öjegen-volme 'hare shaman'; öjegen-purie 'cleft berry, lit. hare's berry'; öjegedie öjegeje 'a female name'; öjege-laqil 'a star constellation, lit. hare's tail'. Throughout the world's languages it is not uncommon to form the word for hare as a derivative of to be fast, swift; in English, for example, there is hare, the fast-running, plant-eating animal of the family Leporidae (genus Lepus) which is similar to a rabbit but larger and with longer ears, but also the connected verb to hare 'to move swiftly'. Also, cf. Ewenki tuksa- 'to run', tuksa-ki 'hare', where hare is derived from the verb to run.

New borrowing

Proto-Tungusic *čanit 'robber; enemy; clan enmity' (TMS 2: 334) > Ewenki čanit ‘бродага; разбойник; фольк. враг; фольк. Название грўппы древнего населения, с которой у тунгўсов бывали столкновёнияrobber = robber; vagabond; enemy (in folklore); name of 


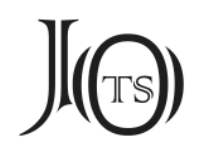

an ancient group of isolated people (in folklore) that the Ewenki had encountered' (Vasilevič 1958:515; cf. Ewenki čani-mī 'бродажничать; разбойничать'), borrowed as: MU tschangd-schama (< ‘̌́an(i)t-šama) 'wolverine (Gulo gulo)' (Nikolaeva 2006: 123).

I suggest that the isolated, documented word for wolverine in MU is an ersatz taboo word, with the elements borrowed from Tungusic. The first part of the compound, čanit, appears to mean 'robber; vagabond, enemy' as borrowed from Ewenki, and the wolverine is indeed sometimes known to act as a sneaky robber or thief in human settlements. The second part of the compound -šama may simply be the widespread word for shaman; among Yukaghirs bears, for example, were believed to be ancient human shamans that had transformed into men of the forests, into bears, and saying its name aloud would summon it, and hence the use of indirect taboo forms. Similarly, using taboo words for wolves, wolverines and other predators would avoid summoning them by mentioning them. The shamans are attributed a wide variety of supernatural abilities, and changing shape or form is one of them, suggesting that a wide variety of different forest animals could be shamans. If this hypothesis is correct, the full compound *čant-šama could be literally interpreted in a number of ways, including robber shaman, or trickster enemy, or even clan enemy vagabond. This could be a fitting epitaph for a stealing, sneaking wolverine, with great reverence and respect given to it in a typical taboo manner. Indeed, in the folklore, for example, among the Frazer river Salish and the Naskapi, the legendary trickster character is exactly a zoomorphic wolverine (Berezkin 2010: 139), which this Yukaghir compound seemingly also describes.

Tentative borrowing

Proto-Turkic *uja '(blood) relation' (EDAL: 1486; VEWT: 511; EDT: 267) > Yakut uja yje 'поколение = generation' (JRS: 450), borrowed as: KD oye 'father'; BO ije 'father' (Nikolaeva 2006: 322).

Two rare words in Yukaghir dialects for father have been documented, and these appear to be Yakut borrowings, with excellent phonological overlap. The Turkic root, from which the Yakut word for generation (and with secondary meanings such as century, medieval, and age) originates, finds different meanings in the different Turkic languages, such as brother, sister, relation, family, kin(sman), 


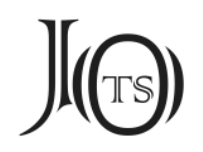

by one venter (=a wife or mother that is a source of offspring), generation, so, essentially the basic original Proto-Turkic meaning must have been blood relation, or relative in a broad sense. The Yukaghir meaning of father also relates to close kin (and reflects a male meaning of by one venter as found in Kyrgyz and KaraKalpak), and could be the result of semantic narrowing during borrowing. Phonologically, the match as a Yakut borrowing in Yukaghir is indeed excellent, particularly from the common form of yje. The BO form of ije 'father' should also be compared to BO úaje 'mother', ${ }^{6}$ which was identified as a borrowing from Yakut ije 'mother' (< Pre-Yakut *ine 'mother') in the last part of this paper series; as such we appear to be dealing with two complementary and very similar forms in BO meaning 'father' and 'mother', respectively, which both ultimately originate from two different Proto-Turkic roots that have almost converged phonologically in Yakut. If correctly identified as a borrowing, the semantic nature of this again suggests extensive familiar bonds between Yakut and Kolyma Yukaghir speakers, likely in a bi- or multilingual environment. The EDAL compares this root with Proto-Tungusic *oji- 'relation, spouse' (TMS 2: 252; cognates are lacking in Ewen and Ewenki, and found only in Negidal, Orok and Solon), as well as ProtoJapanese *əjà 'parent(s)' (JLTT: 514), and indeed these are similar both in phonology and semantics for some reason. Fascinatingly, the Proto-Turkic form *uja has also been suggested borrowed from a Turkic language into Early Middle Chinese as yoe (爺) 'father; grandfather' (along kinship terms for elder brother, mother and elder sister; Vovin 2011: 109).

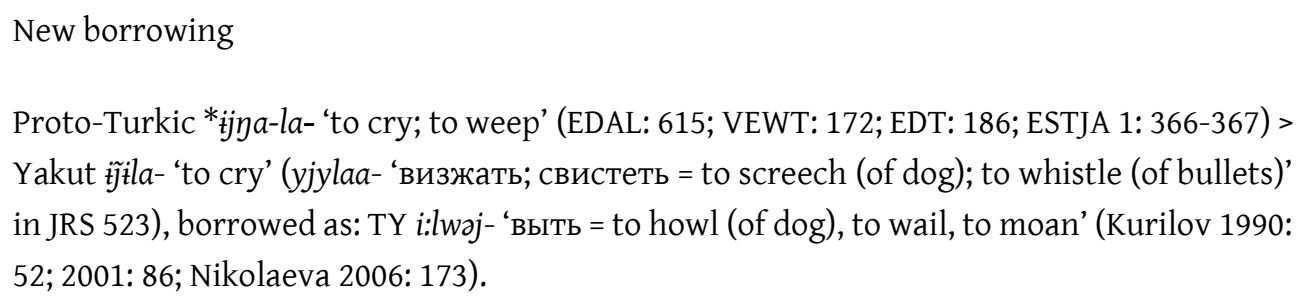

Another verb for to howl is fairly recently borrowed into one Yukaghir dialect only from Yakut. In Tundra Yukaghir, -wə is a common intransitive verbal suffix (< PY *-wo; Nikolaeva 2006: 83) that often appears to materialize as TY -waj

6 Which, I note, should also be compared to non-etymologized MC aya 'sister' (Wrangel 1841: 115); are these actually cognates? 


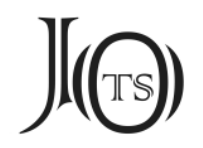

just like with this borrowing. We can thus posit *ijil-waj-, which contain close equivalents to the Yakut sounds of $\dot{i}$ and $\tilde{j}$, respectively, as the borrowed root, which has neatly contracted in the modern language to i:lwaj-. According to Kurilov, this root in TY is also occasionally additionally suffixed with -nu- or -naa-, in particular, given his lexical examples, when describing the howling or wailing of dogs, just like the verb is also used in Yakut.

The EDAL compared the well-attested Proto-Turkic form to the equally well-attested Proto-Mongolic *ujila- 'to cry; to weep' (MGCD: 670; *uila- 'to cry' in Nugteren 2011: 531), although it is clearly difficult to conceive how the rootinternal engma (evident from the Turkish, Tatar, Azerbaijan, Uzbek, Turkmen, Gagauz, Karaim, Karakalpak cognates) would just have disappeared in the Mongolic branch in the case of a common root origin.

\footnotetext{
New borrowing

Proto-Mongolic *ger 'yurt, house' > Written Mongol ger 'yurt; house, dwelling, domicile; home', gergen 'houses' (Lessing 1960: 377), borrowed as: Yakut kergen 'семья, семейство; член семьи, супруг, супруга = family; family member; spouse' (JRS: 220-221; Kałużyński 1961: 28; Stachowski 1993: 145), borrowed as: TK kerge- 'family' (Nikolaeva 2006: 207), probably also: TY kerel'uu( $(y)$ 'families left by reindeer breeders for permanent residence in one place', kerel'uo- 'to spend summer', kerel'uorii- 'to arrange somebody's summer pasture' (Kurilov 1990: 109; 2001: 183).
}

A for Yukaghir unique word meaning family, documented only in TK, originates from an identical Yakut word meaning the same. The same word is seemingly currently found also in modern TY in simplified form kerel'uu (?< *kergel'uu) carrying the nominal derivational suffixes $-l \&-u$ : (< PY *-l \& PY *-u:); Nikolaeva 2006: 81,83; the word still describes families, but the meaning has been semantically narrowed down to only those families which are left along the reindeer trails. The secondary verbal meaning of to spend summer (instead formed by using the TY resultative verbal suffix -ou <-o: (< PY *-əw; Nikolaeva 2006: 82) has no doubt arisen from this meaning as well, which is clarified perfectly by Kurilov's definition of the TY word kerel'uu( $y)$ 'семья или несколько семей, оставленных на постоянное жительство в одной местности в летний период = family or several families left to permanently reside in one location in 


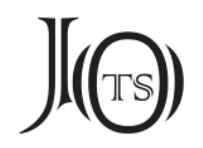

the summer' (Kurilov 2001: 183). Additionally, on the same page he gives TY kerel'uol- 'летовать, жить в одной местности, отстав от кочующих', which confirms and clarifies the semantics of this borrowing.

Where does the Yakut word for family, spouse, i.e. kergen (as well as various suffixed derivatives meaning to woo, to have a family, to get along, to marry, etc.) come from? While I believe it to be a Mongolic borrowing, I must also note that there is a fairly similar Proto-Turkic *gErekü 'tent, yurt; grating of the yurt', although this has so far no suggested Yakut cognate. A connection could exist, but given the phonologically perfect match with the plural Mongolic form * gergen 'houses' (as I have understood the details from literature), a borrowing is more likely in this case, which at any rate requires a semantic change.

\section{Structured semantic fields}

Dividing the found twenty-one borrowings into various cultural and technological spheres of semantics (as per Rédei 1999), produces the following groups:

b. animal kingdom (i.e. fauna): hare (Tungusic); wolverine (taboo form; Tungusic)

d. nature, natural phenomena and natural places: Rapids lake (Tungusic); Gull lake (Eskimo $>$ Tungusic)

g: habitation: untidy (Tungusic); fire(place) (Turkic)

i. social life and kinship terms: father (Turkic); families, to spend summer (Mongolic > Yakut)

1. religion: ancient hanging coffin (Mongolic > Yakut)

m. elementary phenomena, actions and perceptions: to pierce (Tungusic); to stop, to cease (Turkic); to reproach (Tungusic); white (Tungusic); to overtake (Tungusic); to howl (Turkic)

n. other: knot (Tungusic); rust (Mongolic); only, indef.pron.marker (Turkic); modal marker of uncertainty (Tungusic); interjection of fear (Turkic); true (Tungusic).

The following categories had no representatives among the borrowings: a. body parts of humans and animals, c. plant kingdom (i.e. flora), e. types of work and tools, f. trade, h. clothing, j. tribal or population names, $k$. health, illness and death. Again, these results, where borrowings from multiple semantic categories 


\section{J(৫)}

can be noted, well demonstrate the extensive linguistic and social contacts between the historical Yukaghirs and surrounding tribes and languages. 


\section{J(৫)}

\section{Part II}

\section{Introduction}

In addition to suggestions for numerous lexical borrowings into Yukaghir, every part of the paper series also includes some extra topic worthy of discussion. In the first part, details regarding the chronology, phonology, prosody, estimated dating, and so on were presented (Piispanen 2018). In the second part, the whole "Altaic" language hypothesis was discussed, and my own stance on it was made clear as it is relevant for properly understanding the argumentation made in this paper series. In the first part, I suggested corrections to some older Yukaghir documentation, as well as summarized borrowings of grammatical markers (Part I). In this fourth part, I will discuss another tentative nominal derivational suffix, followed by quite a large number of new borrowing suggestions. ${ }^{7}$

\section{Briefly on Para-Yukaghir}

Before proceeding with presenting the suggested borrowings, I will take the opportunity to briefly discuss the hypothetical Para-Yukaghir languages, which, to the best of my knowledge, have not been discussed before in any form. I will claim that the Yukaghir languages are para-Uralic languages, with both the Yukaghir and Uralic languages hailing from a much earlier Pre-Proto-Uralic language (aka. Proto-Uralo-Yukaghir; PUY). Somehow the Yukaghir ended up with the language of one remnant of that old PUY, namely Late Proto-Yukaghir. This hailed from Middle Proto-Yukaghir (MY), which came from Early ProtoYukaghir (EY), which was then fairly close to the PUY stage. This, at least, is what various internal sound laws and comparisons to Proto-Uralic suggests (Piispanen 2013; 2015; 2016a: ii). In this model - which is somewhat similar to making the leap from Proto-Uralic to Proto-Samoyed, which underwent several transitional phonological changes in between in Pre-Proto-Samoyed - there would certainly

\footnotetext{
7 I wish to thank my colleagues Marko CRNOBRNJA, Alexander SAVELYEV, Mikhail ZHIVLOV and Alexander Vovin for their valuable and useful input on an earlier draft version of this paper. All remaining errors are, of course, my own.
} 


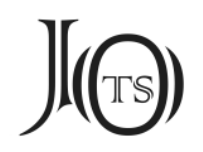

be room for other languages having split off from PUY, EY or MY, respectively, and they would be Para-Yukaghir languages in the strictest sense.

Can any Para-Yukaghir entities be found? Well, for example Omok and Chuvan have lots of non-etymologized words, but they are so different from the other Yukaghir forms that they are hardly to be considered neither Yukaghir, nor Para-Yukaghir, but most likely the influence of other (probably now extinct) local languages (perhaps related to Nivkh, Yup'ik, Chukchi or some unattested language). I do not know exactly how to be able to demonstrate that a word in a non-Yukaghir language is of Para-Yukaghir origin, because the vocalism of irregular borrowed forms alone cannot constitute a criteria. Actually, would not the numerous words being present only in Yakut, Ewen/Ewenki and Yukaghir, as far as I can tell, be suggestive of traces of local, earlier languages in these? But, again, these would not necessarily be Para-Yukaghir. In summary then, specific studies of these words might turn up something, Para-Yukaghir or lost Paleo-Siberian and might provide us with valuable information about the historical language contacts of far Northeastern Siberia.

\section{New borrowings into Yukaghir}

Below I present an additional seventeen new suggested Turkic, Tungusic and Mongolic borrowings into the Yukaghir languages and varieties. These add to the already considerable number of known lexical borrowings into Yukaghir. As noted in earlier parts of this paper series, borrowings are most often to be found when a root is found within a geographically limited area, or solely in Kolyma Yukaghir, Tundra Yukaghir or another older dialect. Borrowings which are found to be very widespread in Yukaghir are logically to be considered very old.

Most often the direction of borrowing is conclusively from a Tungusic or Turkic sources, simply because the word can be traced back even further to the Proto-Tungusic or Proto-Turkic stage (and therefrom into related languages). The usual direction of borrowing is from these languages into Yukaghir, and then particularly into specific dialects only, and we may therefore, as a general assumption, understand these correspondences as Yakut and Tungusic borrowings 


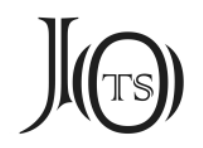

into Yukaghir. While assuming a usual direction of borrowing is not methodologically defensible (as was privately pointed out by CRNOBRNJA and SAVELYEV), I am forced to often make this assumption in this paper. In a few cases, however, the etymology of a Yakut or Ewen/Ewenki word is not at all known. ${ }^{8}$ Then, borrowing from (dialectal) Yukaghir - or even from another earlier now-extinct Paleo-Siberian language - into Yakut and Ewen/Ewenki remains a distinct possibility. The source could even have been Para-Yukaghir as was suggested to me through private correspondence by CRNOBRNJA. In theory, even dialectal Yukaghir forms (or Para-Yukaghir forms) could have been borrowed into the expanding Yakut and Ewen/Ewenki upon contact, a possibility which is made even more likely by the fact that these languages have numerous non-etymologized words (found exactly in Yakut, Ewen/Ewenki and Yukaghir only). However, I will generally consider all the here suggested borrowings to have been from either Yakut or Ewen/Ewenki into Yukaghir (which also includes borrowings between Yakut and Ewen/Ewenki themselves). In a few cases, however, lexical borrowings are found to be so extensive that borrowing chains between a few languages have to be presented and donor and recipient language is not always clear. Below, now, follows seventeen new borrowing suggestions:

\section{Loanword etymology clarification}

Proto-Tungusic *xońi 'sand; dirt' > Ewen onịi ‘sand, dirt' (TMS 2: 220), borrowed as: TY önid'e 'земля; песок; глина = earth; sand; clay' (< *öninća < *öńi -ća), önid'e-legul 'flour, lit. sand food', önid'etke 'a lake's name, lit. sand place'; TK enid'e, önid'e 'sand', etc. (Kurilov 1990: 212; 2001: 356; Nikolaeva 2006: 331).

This Tundra Yukaghir word has previously hesitantly been connected to TU *xońi 'sand; dirt' (EDAL: 839) > Proto-Northern Tungusic *ońi (Nikolaeva 2006:

\footnotetext{
8 As was also mentioned above. In this paper this includes the non-etymologized Yakut words (of possible Paleo-Siberian origin, or Yukaghir borrowings): loy 'a low, prolonged drone, such as of a bell', ana 'epilepsy', ama-du: 'how else; of course (as used actively in dialogues)', ampaalyk 'hubbub, noise, din, turmoil', ed'iij 'older sister (of parent); older relative (of father or mother); aunt, address to middle-aged woman; smallpox', enis- 'to splash strongly, to hit (on the beach, of waves); to wash away (of water on the beach); to souse, to pour', čökö 'neatly, in order, separately'.
} 


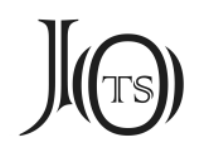

331). However, we may conclude that it is a direct Ewen borrowing simply because there is no Ewenki cognate, and otherwise, to the best of my knowledge, forms are only found in Orok, Oroch and Udege. I suggest that the Ewen word was borrowed, and suffixed into *öníi-ća, which readily became *öninćs (this proto-form is identical to that given in Nikolaeva 2006:331) > KY önid'e.

Semantically, it should be noted that the original meaning in Yukaghir was 'sand' as evident in the older forms, which exactly matches the meaning in Ewen, the donor language.

In comparisons to other languages, the EDAL presents Proto-Turkic *köy 'excrements, faeces; hard soil, swamp' (EDAL: 839, referring to: EDT: 735; ESTJA 5 103); the authors speculate that the Proto-Tungusic form may have arisen through secondary palatalization of a Pre-TU form *xopi-, and offer as evidence Orok xono-kto 'sand'. It is a possibility - although a majority rule would suggest *ń for all of Tungusic - and the Yukaghir form also clearly shows an original *ń at least at the time of borrowing.

New borrowing

Proto-Turkic *jük- 'load', *jüd- 'нагружать = load; to load, to carry' (*jü- in EDAL: 1553, EDT: 885, 910, VEWT: 212, ESTJA 4: 262-263, Leksika: 520) > Yakut sügülün- 'to be lifted on the shoulders or the back; to leave', sügeher 'burden (on the shoulders)', sügeherdee- 'to burden', sügeherden- 'нести = to carry' (JRS: 347-348), borrowed as: (*seje- >) КY šegešej- 'to carry away; fortführen, entführen (TR)', šegišejm ‘увезти = to take away'. (Possibly also: KJ šegešei, čegešei-; KY šejrej- ‘to run away'; KK seyre-; KJ šeure-; M segréinii; KJ šeured'e šeurod'e 'domestic reindeer used to attract wild reindeer') (Nikolaeva-Shalugin 2003: 87; Nikolaeva 2006: 400; Angere 1957: 225).

As suggested both by the phonology and semantics, a borrowing in KY meaning 'to carry' is directly from Yakut. The EDAL actually gives the Proto-Turkic root without the *-k-, but surely it should be part of the reconstruction as it is attested in all of the Turkic languages! More on this below. The change of Proto-Turkic $*_{j-}>$ Yakut $s$ - is, of course, fully regular, as is the change $*_{s-}>$ KY $\check{s}^{-}$ . There is no phoneme $\ddot{u}$ in neither Kolyma nor Tundra Yukaghir, and so the Yakut root, sügü-, was instead borrowed as an equivalent with Yukaghir *seye-. In 


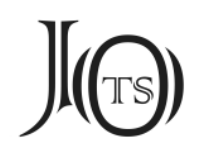

Yukaghir, the principles of synharmonism state that front stems may only contain $k$ and $g$, while back stems only contain $q$ and $\gamma$ (Nikolaeva 2006: 40).

As to the reconstruction, I note that a nominal root of *jük 'load' can be attested in all subsequent Turkic languages. The verbal root ${ }^{*}$ jü-, as given in the EDAL (1553) does not explain the attested forms properly; it should instead be reconstructed as *jüd-, as this finds regular correspondences in Old Turkic jü-d-;

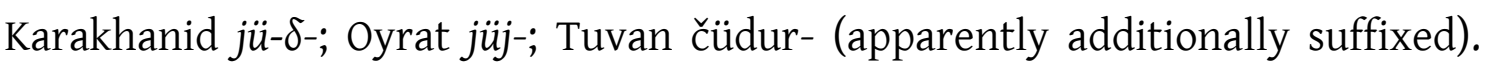
Further similar forms are probably to be found in other Turkic languages as well. Yakut sük- 'to load' and Chagatai yük- 'beladen' appear slightly irregular, but I will suggest that these may be independently developed verbalized nominal stems.

Further, there is also a very similar well-attested Proto-Tungusic *̌̌̆ugū'перетащить = to drag and drop; to carry, to transport' (TMS 1: 269) > Ewen žuүu'перетащить; перенести, перевезти = to drag and drop; to transfer, to transport ; Ewenki ̌̌uүй- 'перетащить; перенести, перевезти = to drag and drop; to transfer, to transport', క̌uүūvun 亏̌uvūvun 'переноска, перевозка; олень, лошадь = carrying, transportation ; reindeer, horse'. The Tungusic root is widely attested also in Negidal, Manchu, Orok, Oroch, and Udeghe. The connection between the Proto-Turkic and Proto-Tungusic roots, if any, is not clear.

Furthermore, there is also well-attested Proto-Mongolic *žöye'перевозить, переносить = to transport, to carry' (KW: 479; MGCD: 456,466), and perhaps Proto-Korean *č̀- 'на взваливать на себя ношу, нести на спине = to shoulder the burden, to carry on one's back' (Liu 1981: 682; Martin et al. 1967: $1527)$ to which to compare. Like the EDAL suggests, the irregular Dagur $\breve{3} u g \bar{a}-$ $\sim \breve{z}$ ugu- 'to carry' is no doubt a Tungusic borrowing. The donor language in the borrowing outlined here into Yukaghir, however, appears to be Yakut due to phonological or geographic reasons. There appears to be several secondarily developed semantic forms (of different suffixation patterns) in Yukaghir from this same borrowed root. 


\title{
$J(\Theta)$
}

New borrowing

Proto-Tungusic *xol-sa 'fish; boiled fish' > Ewenki ollo 'fish', etc. (TMS 2: 14), borrowed as:

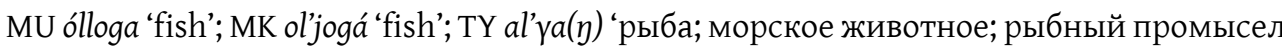
= fish; sea animal; fishery' (< *ol'o-yo, according to Nikolaeva 2006: 325; Angere 1957: 9), ${ }^{9}$ al'yadal'aaj(e) 'fish liver', al'yaduje 'fish fin', al'yannan(')ir 'fish fat', al'yadaavie 'большая ложка = large spoon', al'yadamun 'рыбья кость; высушенный хребет (с мясом) рыбы = fish bone; dried ridge (with meat) of fish', etc. (Atlasova 2007: 11; Kurilov 1990: 25; 2001: 3637).

Also: Proto-Tungusic * xol-sa 'fish; boiled fish' > Ewen olrọ 'fish' (TMS 2: 14), borrowed separately as: TD alha alre ‘fish' (Nikolaeva 2006: 325).

This actually constitutes two separate, but related borrowings into Yukaghir, but from one source: Tungusic. The common word for fish in TY (and MU and MK) is actually an Ewenki borrowing. The older forms, MU and MK, show that this used to be a suffixed three-syllabic root that was o-initial; the original form after borrowing would have been *olloya 'fish' from which all later forms would have developed, including the later TY precursor *ol'o- $\gamma$ a as given by NIKOLAEVA. In parallel, the word for fish in TD was instead borrowed from Ewen (also originating in the same Proto-Tungusic root), as shown by inclusion of the resonant. All of these words thus originate from Proto-Tungusic and describe elementary food-gathering activities between mixed tribes.

\begin{abstract}
New borrowing
Yakut loy ‘низкому протяжному гулу, например болыиого колокола = a low, prolonged drone, such as of a bell', logkunaа- 'издавать низкий протяжный звук (например, о колокола) = to make a low lingering sound (for example of bells)', lonkunas 'густой, громкий и протЯжный (о звуке) = thick, loud and protracted (about sound)', loykunačс̌y 'звучно, протяжно (реветь, кричать) = sonorous, long (of roar, shout, etc.)' (JRS: 230), bor-

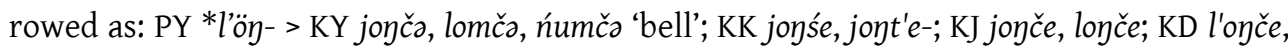
yomče; TY joyče, jöyče; TD -yońče-; RS jonča; KK jonńe- 'ringing'; TY jöyne-, TY jöyerke ‘smth ringing'; joyčen-čoүoyol 'tinkling of a handbell'; jöytege 'name of a place'; jöyniii- 'to make smth ring'; jöyniiiče 'smth ringing' (Nikolaeva 2006: 248).
\end{abstract}

\footnotetext{
9 Additionally, the TD form alxay 'fish' is given elsewhere (Angere 1957: 11), although this clearly only presents a differently transcribed version of TY al' $y a(y)$ 'fish'.
} 


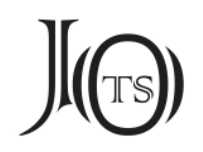

This Yukaghir root, which can be reconstructed at the Late Proto-Yukaghir level, due to extensive lexical spread and attestation, has previously been compared to Khanty (Obdorsk) logxali 'bell' (DEWOS: 845-846). In theory, this could thus represent traces of an ancient common Uralic-Yukaghir cognate, but most likely the dialectal Khanty form was borrowed from a neighboring language, as was likely the Yukaghir form as well, in this case from Pre-Yakut *lon- 'low, prolonged (bell) sound'; the exact phonological form of the borrowed root was still recorded in old Yukaghir, which then underwent palatalization, and the subsequent and fairly expected change of *l'-> j-. Also, since Proto-Turkic did not have root-initial *l- (as was reminded me by SAVELYEV) assuming a Turkic origin for Yakut is on even more shaky grounds. The root itself, which must be very old, is onomatopoetic in origin, and may, I note, actually also exist as Ewenki lugun 'noise, sound, hubbub' > lunu-mī 'to shout; to make noise (of children)' (Vasilevič 1958: 241). The etymology of the Yakut form is not known, but here I have assumed a borrowing therefrom into Yukaghir (regardless of its origin), but the Ewenki and Khanty forms both remain unexplained.

New borrowing

Yakut ana 'epilepsy' (JRS 41), borrowed as: KD ana: 'disease leading to apathy' (Nikolaeva 2006: 106).

In an old document on Kolyma Yukaghir there is an isolated word, ana:, meaning 'disease leading to apathy'. I believe this is a direct lexical borrowing from Yakut ana 'epilepsy' of perfect phonological match (vowel lengthening occurs in Yukaghir due to prosody) even though the etymology of the Yakut word itself is not known. The condition of epilepsy can be very serious and draining and deeply affects the quality of life if left untreated. After an epileptic attack a patient may suffer from disorientation and weakness, ${ }^{10}$ and research has shown that apathy is more frequent among those suffering from epilepsy than those not afflicted. The description in Yukaghir of '... leading to apathy' suggests that it describes a

10 This semantic view is paralleled by the semantic shift found in unrelated Proto-Turkic *dāl- 'to lose strength, to faint, to lose consciousness' > Karakhand talyan ig 'epilepsy' (VEWT: 457; EDT: 490; ESTJA 3: 133-134; EDAL: 1361). 


\section{J(৫)}

disease that progresses slowly to eventually become very detrimental to physical and mental health and well-being. Thus, this borrowing into KD in very high likelihood describes epilepsy.

New borrowing

Yakut ama-du: 'а как же, ещо как; конечно = how else; of course (as used actively in dialogues)' (< ата 'неужели, неужто, наверное = really, indeed, probably') (JRS: 40), borrowed as: KD ama-du 'really, indeed (in questions)' (Nikolaeva 2006: 102).

As is completely clear both phonologically and semantically, a simple expression in the Kolyma Yukaghir dialect denoted KD originated in a Yakut expression used identically in dialogues. The expression, borrowed verbatim, is used to ask about the validity of a fact or used in questions to probe for assurance of fact, and translates simply as 'really?' or 'indeed?', or in colloquial English 'right?'. The etymology of the Yakut ama-du: 'how else, of course' (< ama 'really, indeed, probably') is far from understood or known, and Stachowski considered the possibility of Yakut ama 'einfach, alltäglisch' being of Mongolic origin elsewhere (Stachowski 1995: 126), as suggested in older publications by Kałużyński and Popov, but this still leaves - du: unexplained. That Yakut ama 'einfach, alltäglisch' may even be unrelated to the homonymous Yakut ama 'really, indeed, probably' under discussion here as suggested by the semantic differences. I will instead merely note that there is a hitherto non-discussed but very similar Dolgan amma-da 'was für ein..., welch..., wie...', amma 'Intensivierungswort' (Stachowski 1998: 30) (no doubt from Yakut ama 'really, indeed, probably'), which, if the compound originated in the early Yakut of some four centuries ago, should show that the direction of borrowing should be from Yakut into dialectal Yukaghir. Other comparanda consists of Turkish ama 'however, yet, only'; Azeri amma 'however, while'; Uzbek ammo 'however', but these are generally considered Arabic loanwords, and therefore non-related to the Yakut word at hand. In addition, speculating about Proto-Turkic conjunctions is by default to be considered suspicious, as each conjunction - belonging to higher cognitive vocabulary - probably has a fairly unique history of development in the various Turkic languages. In any case, the suggestion is a borrowing Yakut > Yukaghir. 


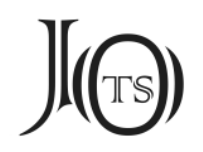

New borrowing

?Proto-Mongolic *aman 'mouth; opening' > Written Mongol ama(n) 'mouth; speech; foodeater; opening resembling a mouth (of a cup, muzzle of rifle, pipe, tube, mountain pass, gulch, ravine, valley, etc.); embouchure' (Lessing 1960: 35), borrowed as: Yakut amaj'широком раскрывать рот (смеясь, улыбаясь) = to open mouth wide (laughing, smiling)', amalij- 'изрекать ; Вещать = to utter; to broadcast', amas gyn (?< *amaj-kün) 'внезапно широко раскрыть рот = to suddenly open one's mouth wide' (JRS: 40), borrowed as: TY amalii- 'to surprise, to amaze', amakaa 'interjection: surprise' (Nikolaeva 2006: 102).

In NIKOLAEVA's dictionary, KD ama-du: (from the above borrowing) was hesitantly compared to TY amalii- 'to surprise, to amaze'. However, on semantic grounds these are not at all connected, and this latter TY root is instead another, separate borrowing. The meaning of 'to (suddenly) open one's mouth' (Yakut) has logically enough become 'surprise' (Yukaghir), as this is perhaps the most common bodily expression of surprise. The suffixation patterns are unclear even though the prosodic forms in both languages are fully valid. Perhaps the roots were borrowed almost verbatim into Yukaghir: TY amalii- is comparable to Yakut amalij-, and TY amakaa is comparable to *amaj-kün (which is given as the original form of amas gyn in the JRS, although I would have expected *amač-kün). From where then does the (to the best of my knowledge non-etymologized) Yakut root hail? I suggest that it is another Mongolic borrowing (see below), as suggested both by the phonology $\left({ }^{*}-\mathrm{m}\right.$ - instead of ${ }^{*}-\mathrm{n}-$ or $\left.{ }^{*}-\mathrm{n}-\right)$ and semantics.

The Yakut root handled here also has counterparts in many of the other surrounding languages: well-attested Proto-Mongolic *aman 'mouth; opening' (Nugteren 2001: 269), a possible source of the Yakut root (which seems to lack a Turkic origin), as well as Proto-Tungusic *am-ya 'mouth; taste' (TMS 1: 38-39) and Ewen ayadaj 'to open; to uncover' (Robbek-Robbek 2005: 44) \& Ewenki a a$m \bar{\imath}$ 'to open; to uncover; to stare; to hoof; to cock a trigger' (Vasilevič 1958: 30) which in turn are comparable to Proto-Uralic *aya- 'to open'; *ane 'mouth; opening' (UEW: 11-12), Late Proto-Yukaghir *aya 'mouth, opening' (Nikolaeva 2006: 106) and even Proto-Eskimo *ayva- 'to be open, hole, cave' > Proto-Yup'ik *ayva(-пәк) 'cave over clavicle' \& Proto-Inupik *agma-ь- 'to be open, to open; hole' (CED 36) and Proto-Chukchee-Kamchatkan *venqŭ- 'открыть(ся) (с коннотациями с ртом) = to open (with connotations to the mouth)' > Proto- 


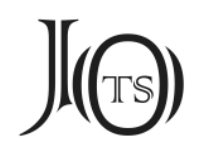

Chukchee-Koryak *feyqu- 'раскрыться; открыться, оскалиться; раскрыть рот; брать в рот, брать взубы; моржовый клык; ножницы = to unfold; to open; grin; to open one's mouth'; to take in mouth or teeth; walrus tusk; scissors' \& ProtoItelmen *'(n)qe- E 'открыть дверь = to open the door'. It seems likely that some similar forms would also exist in Korean, Japanese and Nivkh. These apparently ancient Wanderwörter would seem to originate in an old root containing an engma. Often these roots are further used to derive the secondary meanings of 'to taste', 'to gape', 'to yawn', etc. through different suffixation patterns.

New borrowing

Proto-Turkic *ēnčü 'fief, land and vassals presented by the ruler; gift, dowry', borrowed as: Written Mongolian inže 'dowry', borrowed as: Pre-Yakut *inžä 'dowry' (> Old Yakut *inńä > Yakut enníe enńe änńä ‘приданое = dowry' (JRS: 541)), borrowed as: KD ayčil 'inheritance', ayči- 'to look for; to seek, to search; to inherit', likely also: KD ande 'to deprive of; to cheat a person of his share' (Angere 1957: 21; Jochelson 1926: 318); TD onči- 'to look for; to seek, to search; to inherit', oyčim oyčil 'inheritance' (Angere 1958: 198; Nikolaeva 2006: 329).

Previously, the TD words were non-etymologized, and hesitantly considered as having originated from a Late Proto-Yukaghir root *an- (Nikolaeva 2006: 329). However, with the uncovering of the KD forms the picture becomes much clear, and the words found in both KY and TY can instead be connected to an early Yakut form, from which the root was borrowed. Angere documented the KD word from Jochelson's The Yukaghir and the Yukaghirized Tungus (clearly citing Jochelson, W. 1926:318, who had written the word as a 'ñ ̌́il'; the ñ is Jochelson's transcription for the engma, while the final $-l$ is a nominal derivational suffix and should be non-palatalized), and it well complements the TD form (also from Jochelson) cited in NIKOLAEVA's dictionary. The KD word ande, which in reality was more likely pronounced andə in Kolyma Yukaghir (<*apča), does, on both semantic and phonologic grounds, also belong to this comparison. The Yukaghir words are practically phonologically converged with another word meaning the semantically close 'to look for; to search', but which should have another source of origin. The Yukaghir form clearly shows that this is an old Yakut borrowing, actually from Pre-Yakut *inžă 'dowry' (into both KY and TY), before a regular assimilative change (completed by the $18^{\text {th }}$ century) had produced old Yakut 


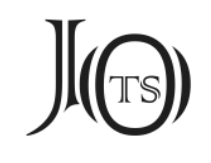

*inńä (as per Stachowski 2005: 195). The phoneme ž was lacking in Yukaghir and thus instead became a $\check{c}$, from where further phonological changes could occur. The Yukaghir vocalism is irregular to start with, which is due to this being a borrowing; most likely, the vocalism does reflect attempts at reaching Yukaghir vowel harmonism for this root.

The Yakut root, due to phonological reasons, is actually yet another Mongolic borrowing, which, however, earlier had been borrowed into Mongolic from a Turkic source: Proto-Turkic *ēnčü 'fief, land and vassals presented by the ruler; gift, dowry' (VEWT: 44, EDT: 173, ESTJA 1: 361-362, Leksika: 347-348, Dybo 1997), which literature agreeably maintains was borrowed as Middle Mongol enčü, Written Mongolian inže, Kalmuck inక̌a 'dowry' (KW: 208, 296). Some researchers (Haenisch 1939: 82; TMN 2: 224; EDT: 173) suggest that Written Mongolian inže is instead a Chinese borrowing, and that the modern Turkic forms may reflect a confusion of the original form and the later mongolism. To me, however, this does not sound like a plausible explanation, and this is likely yet another Turkic > Mongolic > Yakut borrowing, which then found itself into Yukaghir. Semantically, a dowry is fully comparable to inheritance, which offers no further obstacles for this borrowing suggestion. The nature of this borrowing does, again, show the close ties between historical Yakut and Yukaghir speakers, as well as the fairly deep influences of Mongolic on Yakut.

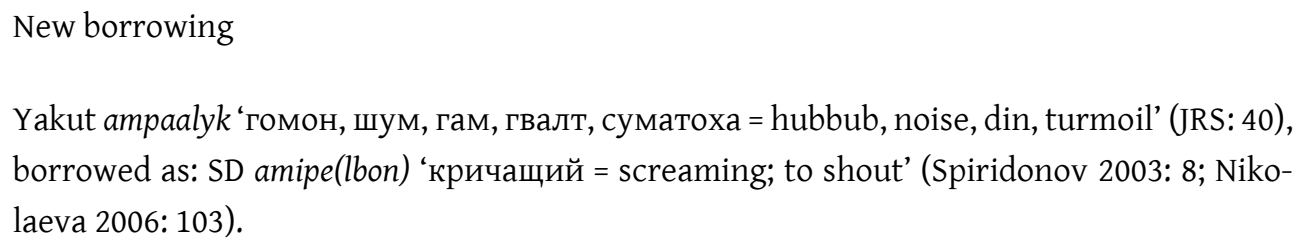
borrowed as: SD amipe(lbon) 'кричащий = screaming; to shout' (Spiridonov 2003: 8; Nikolaeva 2006: 103).

An unique word for to shout documented in SD - a Kolyma Yukaghir dialect - only is borrowed from a Yakut word meaning noise, turmoil. The borrowing was truncated in typical Yukaghir fashion and the cluster gained an epenthetic $-i-$ perhaps in order to avoid homonymy with SD abudaj- 'to stretch' (<*ampu-daj) or PY *ampa 'disk or hook on a ski made of birch bark tightened with a piece of leather' (Nikolaeva 2006: 116) if it existed in SD; it likely did, but the records of SD recorded by Spiridonov are quite fragmentary and by no means complete. So, 


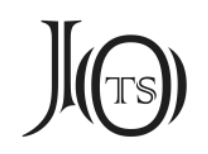

the borrowed form should have looked something like *am(i)pel-bon, with the last segment being unclear. While the Yakut etymology is not known, we should consider this a standard Yakut borrowing into a local dialect of Yukaghir only.

Semantically, it is possible to connect to shout to general loudness, noise or hubbub. In the JRS, the word is given with an example meaning: такой гомон, что ничего нельзя разобрать = such a hubbub that nothing can be made out, which suggests a situation which is so loud overall that no specific sounds or meanings can be made out by the listener, which would happen for example in a rowdy crowd of people shouting.

\begin{abstract}
New borrowing
Yakut ed'iij 'старшая сестра (родная); старшая родственница (по линии отца или матери); тетка, тетя, тетенька (обращение к женцине средних лет); оспа = older sister (of parent); older relative (of father or mother); aunt, address to middle-aged woman; smallpox' (JRS: 537), borrowed as: *ed'i-u: *ejd'i-u: > TY ewd'uo 'тетя (единоутробная, двоюродная сестра отца) = aunt; father's cousin or half-sister'; TK ewd'uo, ewd'uop 'father's younger sister'; TJ eid'uo 'father's younger sister or younger female cousin' (Kurilov 2001: 579; Nikolaeva 2006: 166).
\end{abstract}

Another kinship term, a regular term meaning mainly 'aunt', is found borrowed into Tundra Yukaghir and dialects from Yakut. Morphologically speaking, the borrowed root was suffixed with the nominal derivational suffix - $u$ : (Nikolaeva 2006: 83), while the semi-vowel -w-, which is known to have arisen secondarily root-internally (Piispanen 2016b: 275-279), is just epenthetic having naturally arisen in this environment. We can reconstruct either a predecessor borrowed form of *ed'i-u: or *ejd'i-u:, first forming the TJ form, and later developing into * ewd'uo in TY. ${ }^{11}$

Semantically, the original meaning of aunt has undergone secondary developments in Yukaghir into not only including the sister of a parent, but also their female cousins, which thus in relation to the speaker are second cousins. How the

11 NiKolaEva's dictionary reconstructed the Late Proto-Yukaghir root * ewnčo: for these Yukaghir words, but this borrowing shows that this is unnecessary; in fact, I do not personally believe that Late ProtoYukaghir even had the cluster ${ }^{*}$-wnč-, as root-internal ${ }^{*}-w_{-}$had developed secondarily from several other phonological sources. 


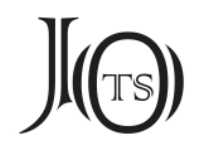

meaning of 'smallpox' has arisen for this word is semantically not clear. While the Yakut etymology is not known, there have been made numerous kinship borrowings into Yukaghir both from Yakut and Ewen/Ewenki, and we may assume that this is another borrowing in that direction.

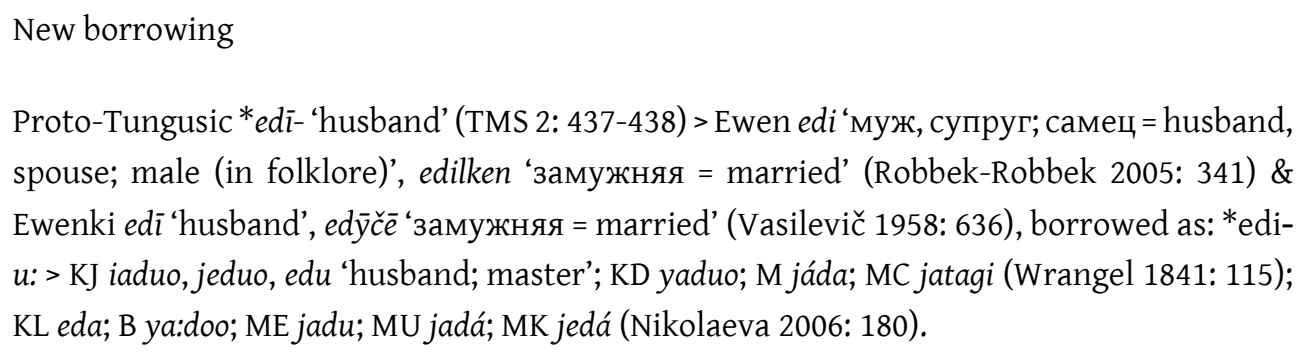
spouse; male (in folklore)', edilken 'замужняя = married' (Robbek-Robbek 2005: 341) \& Ewenki edī 'husband', edȳč ‘ ‘замужняя = married' (Vasilevič 1958: 636), borrowed as: *ediu: > KJ iaduo, jeduo, edu 'husband; master'; KD yaduo; M jáda; MC jatagi (Wrangel 1841: 115); KL eda; B ya:doo; ME jadu; MU jadá; MK jedá (Nikolaeva 2006: 180).

Yet another kinship borrowing created in a very similar pattern to the above originates in a phonologically similar, but semantically different, Tungusic word (instead of a Turkic word). NIKOLAEVA reconstructs a Late Proto-Yukaghir

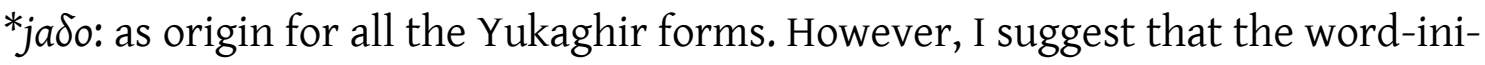
tial $j$-in most forms is either a Russian influence on local Yukaghir pronunciation or erroneous recordings of many older forms (which can be fairly often observed) with Rus. $e$ (je) instead of $ə$ (e). After borrowing, most forms carry the nominal derivational suffix -u: (Nikolaeva 2006: 83). I would rather reconstruct *edi-u:, very close to the reconstructed form of the previous kinship borrowing (see above). A few, like KJ edu; KL eda more closely resemble the original Ewen form of edi as if non-suffixed. The Tungusic word additionally appears to have both Turkic and Mongolic correspondences with Proto-Turkic *edi 'host' (ESTJA 1: 237-241, TMN 2: 176, EDT: 41, Leksika: 324-325) and Proto-Mongolic *ežen 'host' (EDAL: 493).

New borrowing

Proto-Tungusic *epo 'wet', *xepe- 'to sprinkle, to get wet' (TMS 2: 459-460, *xep- in EDAL: 779) > Ewen eb ер 'сырость, мокрота, влага; мокро, влажно, сыро = dampness, sputum, moisture; wet, damp' (Robbek-Robbek 2005: 338) (Ewenki epo 'wet', etc.; Negidal epti- 'to splash'; Orok xepičči- 'to sprinkle'; Manchu ebe- 'to get wet', ebene- 'to soak'), borrowed as: TY ebekie 'dampness' (Kurilov 2001: 578; Nikolaeva 2006: 159). In Ewen other apparently related words are also to be found: ebdej 'to sprinkle (of rain)', ebe 'urine, ebèdej- 'to urinate', eben 'moisture', etc. 


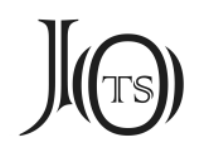

A rare, isolated TY word meaning dampness was borrowed from an Ewen word meaning exactly the same. While the TY form was given a Late ProtoYukaghir reconstruction of *empəke: in NIKOLAEVA's historical dictionary, it is unnecessary because this is a recent Ewen borrowing, as demonstrated by the straight-forward phonology and semantics. After borrowing, the root was suffixed with -kie(n), a common TY nominal derivational suffix (also oddly found with some verbs including in this case) usually used with names (Piispanen 2016a: 214), cf. TY anakie 'a man in folklore, lit. mountain dweller' (< TY anaa 'mountain'); TY nereguukien 'a man in folklore' ( $<$ TY nereguo- 'lean; thin'); TY čindilikeen 'a man in folklore, lit. snipe-man' (cf. KY čindi: 'lark'); TY lerpukie 'hairy male dog' (< TY lerpune- 'hairy'); TY lirukie 'smth with long fur' (< TY liručeń- 'to have long fur (INTR)'; TK liteged'iekie 'hammer for forging' ( $<$ TY liteged'i- 'to forge').

Note also that the Tungusic word, existing both as early nominal and verbal roots (the latter of which should probably be reconstructed *xepe- as I give it above, instead of merely *xep-; in reality, the nominal form was probably also likewise Proto-Tungusic *xepo 'wet') appears to have a related Turkic root with well-attested Proto-Turkic *jebi- 'to become wet, soak' (EDAL: 472; EDT: 872; VEWT: 202; ESTJA 4: 196-197), although it seems as if most languages actually point at ${ }^{*}$ jip- or *jep- instead (as agreeably suggested also in EDAL: 472). The Yakut cognate is the regularly formed sibin- 'fresh', which due to phonological and semantic reasons cannot be the donor language in this case. So, the TY form was likely borrowed and suffixed as *(x)epe-kie 'dampness'.

New borrowing

Yakut eyis- 'сильно плескать, ударять (о берег - о волнах); подмывать (берег - о воде); окачивать, обливать = to splash strongly, to hit (on the beach, of waves); to wash away (of

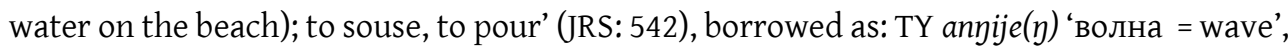
anyijerej- 'стать волнистым (об озере, реке) = to become wavy (about a lake, or river), anyijeń- 'быть волнистым, иметь волны = to be wavy'; ТK anjije 'wave', anyijere- 'to be rough; to rise in waves (of the sea)'; TD ańie- 'wave' (Kurilov 2001: 46; Nikolaeva 2006: 109). 


\section{$J(\Theta)$}

This constitutes a fairly recent borrowing as there are no phonological traces in Yukaghir of what must have been the Pre-Yakut verbal form *enič-. Rather, the final suffix has been cut off with the borrowing, and in Yukaghir, the $j e$ is instead a nominal derivational suffix commonly attached to a verbal root; cf. TY kirije 'name'; TY kindije 'dump'; TY kiiwije 'fontanel'; TY kurije 'family, clan'; TY lalwije 'extra blanket'; TY liteged'ije 'forger', etc. The root-initial vowel has been backed for some reason, but despite that this is to be considered a secure borrowing.

Semantically, to splash strongly and waves hitting the beach (Yakut) is indeed synonymous with to become or be (roughly) wavy (Yukaghir). The Yakut etymology is not known, but we may again assume the direction of borrowing of Yakut > Yukaghir.

\footnotetext{
New borrowing

Proto-Tungusic *b[ü]lkü- 'смочить, намочить; плескаться, бить ключом = to soak, wet; to splash, swash' > Ewenki bilki- 'смочить, намочить (шкуру при выделке) = to wet (skin during dressing)'; bulkiw- 'плескаться, бить ключом = to splash, to bubble', bulku-mī 'to lubricate, to anoint, to paint, to wet, to wash', bulkukit 'bathhouse' (Vasilevič 1958: 66; TMS 1: 82,108), borrowed as: *polki- > TY pöwgii- 'to strike something on water producing splashes (TR)', pöwgej-, pewgej- 'to splash (especially of a fish)', pewdi- 'to splash many times' (Nikolaeva 2006: 363).
}

Another borrowing, related to splashing and water is found from Ewenki into Tundra Yukaghir only. We may posit an early borrowed form of * polki- 'to splash' in Yukaghir (< Ewenki bulkiw- 'to splash'). The cluster *-lk- - which regularly changes in different ways in Yukaghir - then underwent a sonorization type of lenition with $l$-vocalization, which produced the semivoweled form ${ }^{*}$-wk-. Indeed, all root-internal ${ }^{*} w$ in Yukaghir have been produced secondarily from a number of other phonemes far after the universal change of $*_{-w_{-}} *_{-j}-$ had occurred in all forms of Yukaghir. This very early phonological change, possibly already in Early Proto-Yukaghir, changed the phoneme ${ }^{*} w$ in all positions except for root-initially, and only later was it "regenerated" root-internally and -finally (Piispanen 2016b), like apparently with this borrowing. Then, like NiKolaEVA 


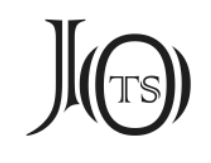

notes, in some forms the vowels have been labialized under the influence of labialized consonants, which describes the fronting and raising of the vowels. The semantic overlap of 'to splash' and derivatives thereof is most satisfactory, securing this borrowing suggestion.

\begin{abstract}
New borrowing
Yakut čökö ‘аккуратно, в порядке, отдельно = neatly, in order, separately’, čököt 'ставить, расставлять (аккуратно, отдельпо); уточнять = to put, to set up (neatly, separately); to specify' (JRS 512), borrowed as: TY čоүutney 'аккуратно = neatly', čoүutne-nigerej- 'отделить от целого = to separate from the whole, lit. to place somewhere separately' $(<$ TY nigerej'to place somewhere'), čoүutne-kurčij- 'стать аккуратной (не разбросанной) группой (о стаде оленей) = to become a neat (not scattered) group (of a herd of deer), lit. to become in order' (< TY kurčij- ‘to become, to happen') (Kurilov 1990: 326, 2001: 558; Nikolaeva 2006: 137).
\end{abstract}

As evident from the Yukaghir compounds, the borrowed form into TY clearly means not only neatly, but also in order (i.e. to become in order, not to become neat) and separately (i.e. to place somewhere separately, not to place somewhere neatly), just as was the original meaning also in Yakut, in order for the semantics to make sense. The etymology of this Yakut word is also not known, but we may have a comparandum with Ewen čakuti 'ok, accurate, thoroughness' (Robbek-Robbek 2005: 327) but the vocals speak against there being any connection. As my colleague M. CRNOBRNJA suggests in private correspondence another comparandum is Manchu čoho- 'to do especially, to consider as the most important aspect, čohome 'especially, on purpose, particularly, exclusively', which may be related to Written Mongolian čoqu- 'to agree', but the phonology seems insurmountable. At this point, we will again (by default as this is practically always the case) have to assume the direction of borrowing of Yakut > Yukaghir.

New borrowing

Proto-Tungusic * čeče 'rag, patch' (TMS 2: 422) > Ewen čeče 'кусок, лоскуток; куски, лоскутки, обрезки ткани, кожи = piece, shred; pieces, patches, scraps of fabric, leather', с̌ес̌egdej- 'резать, разрезать на мелкие куски, лоскутки = to cut, to cut into small pieces' (Robbek-Robbek 2005: 338)(\& Ewenki čeče ‘shred, patch'; Negidal čeče, Literary Manchu čeče 'silk fabric'), borrowed as: KJ čid'e čiid'e 'piece'; TY čid'e čiid'e 'нижняя часть женского 


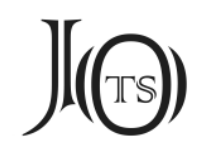

кафтана (примерно от живота до края подола), обшитая кусками собачьей шкуры и бахромой (передняя часть выше чиидьэ бахромы не имеет = in short: bottom part of a woman's coat trimmed with dog fur and tassels' (Kurilov 2001: 549; Nikolaeva 2006: 132), KD čiže 'piece' (Angere 1957: 37; actually given as cize according to ANGERE's transcription system).

The semantic overlap between Ewen 'pieces, patches, scraps, leather' is excellent with TY 'bottom part of coat trimmed with dog fur and tassels', whereas in KY only the meaning of 'piece' seems to have been borrowed. While semantic narrowing over time is possible (changing the meaning in one Yukaghir branch), it is equally possible that this word was independently borrowed from Ewen into both KY and TY at different times with different meanings. In Kolyma Yukaghir transcription, $d$ ' and $z$ are to be considered interchangeable signifying the same phoneme. The vocalism and various Yukaghir forms therefore do suggest an underlying borrowed * čiže from the original čeče, somewhat irregularly, perhaps in order to avoid homonymy with for example KY čečemu- 'to flash, to gleam'.

The EDAL (1331) speculates that the Ewen, Ewenki and Negidal forms may be Manchu borrowings, although the semantic overlap is poor (silk fabric is certainly NOT rags) and there are no really good reasons for assuming so, other than allowing for an earlier hypothetical, pre-assimilated Manchu form * šě̌e, which could perhaps then be comparable to well-attested Proto-Turkic *sačuk 'fringe, handkerchief with a fringe' (VEWT: 392; EDT: 795-796) and the, from Turkic borrowed, Written Mongolian sača $\sim$ čačay (I was unable to find the meaning of this EDAL-given word in Lessing 1960) (and Kalmuck cacag 'fransen, quasten, büschel' (KW: 423). I believe that the EDAL indirectly suggests Written Mongolian as the donor language for a borrowing first into Manchu, and from there subsequently into the northern Tungusic languages, but this is only somewhat possible due to the aforementioned reasons. In any case, the source of the Yukaghir forms is most likely the Ewen language (albeit Ewenki would also be possible even if it seems less likely).

\section{Structured semantic fields}

Dividing the found borrowings into various cultural and technological spheres of semantics (as per Rédei 1999), produces the following groups: 


\section{J(৫)}

b. animal kingdom (i.e. fauna): fish (Ewenki), fish (Ewen)

d. nature, natural phenomena and natural places: sand (Ewen); dampness (Ewen); wave; to splash (Yakut); to splash (Ewenki)

e. types of work and tools: bell; ringing (Yakut)

h. clothing: piece of clothing (Ewen)

i. social life and kinship terms: dialogue expression (Yakut); inheritance (Turkic > Mongolic

> Yakut); aunt (Yakut); husband; master (Ewen)

k. health, illness and death: epilepsy (Yakut)

m. elementary phenomena, actions and perceptions: to carry (away) (Yakut); surprise (Mongolic > Yakut); screaming (=loud noise) (Yakut)

n. other: neat; in order (Yakut)

The following categories had no representatives among the borrowings: a. body parts of humans and animals, c. plant kingdom, f. trade, g. habitation, j. tribal or population names, 1. religion. The borrowings are again spread out throughout multiple semantic categories, which continues to demonstrate the extensive linguistic and social contacts between the historical Yukaghirs and surrounding tribes and languages.

\section{Abbreviations}

$\mathrm{B}=$ Materials of Billings 1787 .

$\mathrm{BO}=$ Materials of Boensing 1781.

$\mathrm{CED}=$ Fortescue et al. 2001.

DEWOS = Steinitz 1966-1993

$\mathrm{EDAL}=$ Starostin et al. 2003.

$\mathrm{EDT}=$ Clauson 1972 .

ESTJA = Sevortjan 1974-2000.

FEDOTOV 1 = Fedotov 1995.

FEDOTOV 2 = Fedotov 1996. 


\section{$J(\Theta)$}

JLTT = Martin 1987.

JRS = Slepcov 1972

$\mathrm{KD}=$ Kolyma Yukaghir from Jochelson's manuscript dictionary.

KJ = Kolyma Yukaghir materials of Jochelson 1898 and 1900.

KK = Kolyma Yukaghir materials of Krejnovič 1982.

$\mathrm{KL}=$ Materials of Klitschka 1781.

KW = Ramstedt 1935.

$\mathrm{KY}=$ Modern Kolyma Yukaghir.

Leksika = Tenišev 1997.

$\mathrm{M}=$ Materials by Maydell presented by Schiefner 1871a and $1871 \mathrm{~b}$.

MC = Chuvan materials of Matjuškin in Wrangel 1841.

$\mathrm{ME}=$ Materials of Merk 1787.

MGCD = Menggu yuzu yuyen cidien, Qinghai, 1990.

MK = Kolyma Yukaghir materials of Mueller and Lindenau in 1741.

MO = Omok materials of Matjuškin in Wrangel 1841.

MU = Ust'-Janskoe materials of Mueller/Lindenau 1741.

RS = Materials of Rajskij and Stubendorf presented by Schiefner 1871a.

SD = Kolyma Yukaghir materials of Spiridonov 2003.

$\mathrm{SU}=$ Materials by Suvorov presented by Schiefner 1871a.

$\mathrm{TD}=$ Tundra Yukaghir materials of Jochelson 1926.

TK = Tundra Yukaghir materials of Krejnovič 1958 and Krejnovič 1982.

TMS 1: = Cincius 1975.

TMS 2 = Cincius 1977

TY = Modern Tundra Yukaghir.

UEW = Rédei 1988-1991.

VEWT = Räsänen 1969. 


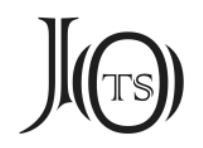

$\mathrm{W}=$ Early materials of Witsen in 1692. All the older materials are fully described and referenced in Nikolaeva 2006.

\section{References}

ANGERE, J. (1957). Jukagirisch-Deutsches Wörterbuch, Wiesbaden: Otto Harrassowitzh.

ANIKIN, A. E. (2000). Etimologičeskij slovar russkix dialektov sibiri, zaimstvovaniya iz ural'skix, altajskix i paleoaziatskix jazykov, Moscow-Novosibirsk: Nauka.

ATlasova, E. S. (2007). Slovar' jukagirsko-russkij i russko-jukagirskij (tundrenyj dialekti) - okolo 3500 slov, St. Peterburg: Filial izdatel'stva <prosveshchenije>.

BEREZKIN, Y. (2010). “Tricksters trot to America - areal distribution of folklore motifs", Folklore, 46: 125-142.

Cincius, V. I. (1975). Sravnitel'nyj Slovar' Tunguso-Man'žurskix Jazykov I, Leningrad: Akademia Nauka.

Cincius, V. I. (1977). Sravnitel'nyj Slovar' Tunguso-Man’žurskix Jazykov II, Leningrad: Akademia Nauka.

CLAUSON, Sir G. (1972). Etymological dictionary of Prethirteenth Century Turkish, Oxford: Clarendon.

DOERFER, G. (1985). Mongolo-Tungusica, Wiesbaden: Harrassowitz.

Dyво, A. V. (1997). Nazvanija podarkov v praaltajskom, Honour of the 90th Anniversary of N. A. BASKAKOV, Moscow: Languages of Russian Culture.

FEDOTOV, M. R. (1995). Ėtimologičeskij slovar’ čuvaškogo jazyka, Tom I: A-Rintăvan, Čeboksary: Čuvaškij gosudarstvennyj institut gumanitarnyx nauk.

FEDotov, M. R. (1996). Ėtimologičeskij slovar' čuvaškogo jazyka, Tom II: SavYaštaka, Čeboksary: Čuvaškij gosudarstvennyj institut gumanitarnyx nauk.

ForTescue, M. et al. (2001). Comparative Eskimo Dictionary: with Aleut Cognates, Alaska: University of Alaska Press.

GomвосZ, Z. (1912). Die bulgarisch-türkische Lehnwörter in der ungarischen Sprache, Helsinki: Suomalais-Ugrilaisen Seuran Toimituksia.

HAENISCH, E. (1939). Wörterbuch zu Mangholun Niuča Tobčaan (Yüanchsao pishi), Geheime Geshichte der Mongolen, Leipzig: Harrassowitz. 


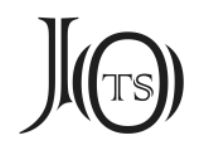

Jochelson, W. (1898). “Obrazcy materialov po jukagiskomu jazyku i fol'kloru, sobrannye v Jakutskoj ekspedicii”, Izvestija Imperatorskoj Akademii Nauk, 8: 151-177.

JoCHELSON, W. (1900). Materialy pojukagirskomu jazyku i fol'kloru I, St Petersburg.

Jochelson, W. (1926). The Yukaghir and the Yukaghirized Tungus, New York: G. E. Stechert American Agents.

KAŁUŻYŃSKI, S. (1961). Mongolische Elemente in der jakutischen Sprache, Warzawa: Państwowe Wydawn.

KałUŻYŃski, S. (1995). Iautica: Prace językoznawcze, Warszawa: Wydawnictwo Akademickie Dialog.

KuRILOv, G. N. (1990). Jukagirsko-russkij slovar', Akademija Nauk SSSR, Jakutsk: Jakutskoje knizhnoje izdatel'stvo.

KuRILOV, G. N. (2001). Jukagirsko-russkij slovar', Rossiskaja Akademija Nauk, Novosibirsk: Sibirskoje otdelenije institut problem malocislennyx narodov severa.

LESSING, F. D. (1960). Mongolian-English Dictionary, Los Angeles \& Berkeley: University of California Press.

LIU (1981). Liu Zhaoxiong. Dongxiang yu jianzhi. Beijing.

LORÁND, B. (1967-1976). A magyar nyelv történeti-etimológiai szótára I-IV, Budapest: Akadémiai Kiadó.

MARTIN, S. E. (1987). The Japanese Language through Time, New Haven-London: Yale University Press.

MARTIN, S. E. et al. (1967). A Korean-English Dictionary, New Haven-London: Yale University Press.

Maslova, E. (2003). A Grammar of Kolyma Yukaghir, Berlin: Mouton de Gruyter.

Nam Kwang, U. (1960). Koe sacen, Seoul.

NiKolaeva (2006). A Historical Dictionary of Yukaghir, Berlin \& New York: Mouton de Gruyter.

Nikolaeva A. \& V. G. Shalugin (2002). Slovar' Jukagirsko-Russkij i Russkij-Jukagirskij (Verxnekol'mskij Dialekt), St. Petersburg: Izdatel'stvo "Drofa”.

Nugteren, H. (2011). Mongolic phonology and the Qinghai-Gansu Languages, Utrecht: LOT. 


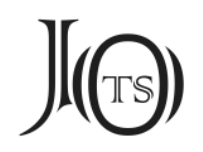

PEKARSKY, E. K. (1959). Slovar jakutskogo jazyka I-III, Akademija Nauk SSSR, Yakutsk.

PIISPANEN, P. S. (2013). “The Uralic-Yukaghiric connection revisited: Sound Correspondences of Geminate Clusters", Journal de la Société Finno-Ougrienne, 93: 165-197.

PIISPANEN, P. S. (2015). “Evaluating the Uralic-Yukaghiric word-initial, proto-sibilant correspondence rules", Journal de la Société Finno-Ougrienne, 95: 237-273.

PIISPANEN, P. S. (2016a). "Folklore borrowings in north-eastern Siberia", Turkic Languages, 20: 257-272.

PIISPANEN, P. S. (2016b). "A prosody-controlled semi-vowel alternation in Yukaghir", Journal of Historical Linguistics, 6/2: 247-296.

PIISPANEN, P. S. (2017). “Folklore borrowings in north-eastern Siberia”, Turkic Languages, 20: 257-272.

PiIsPanen, P. S. (2018). "Additional Turkic and Tungusic borrowings into Yukaghir", Turkic Languages, 22: 108-138.

PiISPANEN, P. S. (2019). “Additional Turkic and Tungusic borrowings into Yukaghir II”, Journal of Old Turkic Studies, 3/1: 54-82.

RAMSTEDT, G. J. (1935). Kalmückisches Wörterbuch, Helsinki: Suomalais-Ugrilainen Seura.

RÄSÄNEN, M. (1969). Versuch eines etymologisches Wörterbuchs der Türksprachen, Helsinki: Suomalais-Ugrilainen Seura.

RÉDEI, K. (1988-1991). Uralisches etymologisches Wörterbuch, Budapest: Akadémiai Kiadó.

RÉDEI, K. (1999). “Zu den uralisch-jukagirischen Sprachkontakten”, Finnisch-Ugrischen Forschungen, 55: 1-58.

Roвbeк, V. A. \& M. E. Rоввек (2005). Evensko-Russkij slovar', Novosibirsk: <Nauka>. Sibirskaja izdatel'skaja firma RAN.

RozYCKI, W. (1994). Mongol Elements in Manchu, Indiana, Bloomington: Research Institute for Inner Asian Studies.

SANZHEEV, G. D. et al. (2015a). Etimologičeskij slovar' mongol'skix jazykov I: A-E, Moscow: Institut Vostokovedenija RAN. 


\section{J(৫)}

SANZHEEV, G. D. et al. (2015b). Etimologičeskij slovar' mongol'skix jazykov II: G-P, Moscow: Institut Vostokovedenija RAN.

SCHERBAK, A. M. (1997). Rannije Turko-Mongol'skije yazykovyje svjazi VIII-XIV vv., St. Petersburg: ILI RAN.

SCHIEFNER, A. (1871a). "Beiträge zur Kenntnis der jukagirischen Sprache”, Bulletin de l'Académie Impériale des Sciences, 3/16: 373-399.

SCHIEFNER, A. (1871b). “Über Baron Gerhard von Maydell's jukagirische Sprachproben”, Mélanges Asiatiques, 6/5: 600-626.

SeVoRTJAN, E. V. (1974-2000). Ėtimologičeskij slovar' tjurskix jazykov I-VI, Moscow: Izdatel'stvo "Nauka".

SLEPCov, P. (1972). Jakutsko-russkij slovar', Moscow: Sovetskaja Ekciklopedija.

SPIRIDonov, N. I. (2003). Jukagirsko-russkij slovar' i évensko-russkij slovar', Jakutsk: Yakut State University Publishing House.

SPIRIDonov, V. K. (1997). Shkol'nyj russko-jukagirskij slovar', Jakutsk: Ministerstvo obrazovanija respubliki Saxa (Jakutija).

StAcHowsKi, M. (1993). Dolganischer Wortschatz, Kraków: Uniwersytet Jagiellónski Kraków.

StachowsKi, M. (1995). “Arabische Etymologien in der Geschichte der Jakutischen Wortforschung”, Zeszyty Naukowe UJ. Prace Języko-znawcze, 117: 125-138.

Stachowski, M. (1998). Dolganischer Wortschatz Supplementband, Kraków: Ksiegarnia Akademicka.

StachowsKi, M. (2005). "Chronology of some Yakut phonetic changes in the context of $18^{\text {th }}$ century Mongolian loanwords into Yakut", Rocznik Orientalistyczny, 58: 194-203.

Starostin, S. et al. (2003). An Etymological Dictionary of Altaic Languages I-III, Leiden: Brill.

STEINITZ, W. (1966-1993). Dialektologisches und etymologisches Wörterbuch der ostjakischen Sprache (unter Mitarbeit von Liselotte Böhnke Gert Sauer und Brigitte Schulze) I-XV, Berlin: Akademie-Verlag.

TENIŠEv, E. R. (1997). Sravnitel'noistoričeskaja grammatika tjurskix jazykov: Leksika, Moscow: Akademia Nauk. 


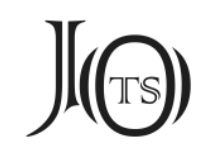

VASILEVIČ, G. M. (1958). Evenkijsko-Russkij Slovar', Moskva: Gosudarstvennoje isdatel'stvo inostrannyx i natsional'nyx slovarej.

VAsILIEV, Y. (1995). Türkçe-Sahaça (Yakutça) Sözlük, Ankara: Türk Dil Kurumu Yayınları.

Vovin, A. \& D. Mccraw (2011). “Old Turkic Kinship Terms in Early Middle Chinese”, Türk Dili Araştırmaları Yıllığı Belleten 2011/1: 105-116.

Vovin, A. (2015). "Eskimo loans in North Tungusic", Iran and the Caucasus, 19: 8795.

Wrangel, F. von (1841). Putešestvie po severnym beregam Sibiri i po Ledovitomu morju, soveršennoe v 1820, 1821, 1822, 1823 i 1824 godax èkspediciju, sostojavšeju pod načal'stvom flota lejtenanta Ferdinanda fon Vrangelja I-II, St. Petersburg. 